\title{
Last interglacial (MIS 5e) sea level determined from a tectonically stable, far-field location, Eyre Peninsula, southern Australia
}

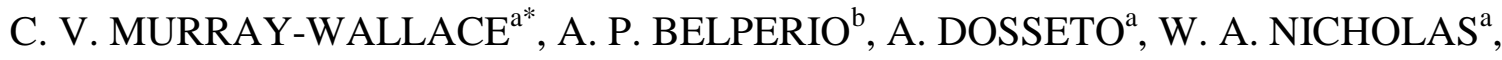 \\ C. MITCHELL ${ }^{\mathrm{a} \dagger}$, R. P. BOURMAN ${ }^{\mathrm{a}}$, S. M. EGGINS ${ }^{\mathrm{c}}$, AND R. GRÜN $^{\mathrm{c}}$
}

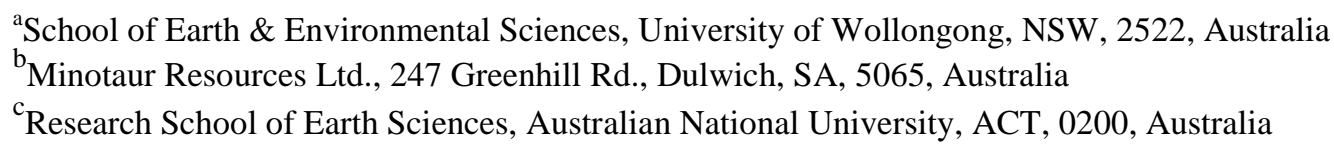

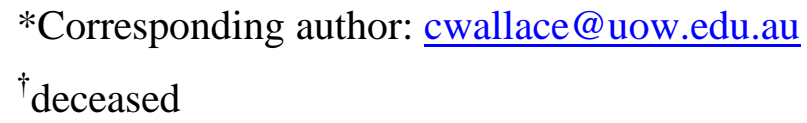

\section{ABSTRACT}

The Last Interglacial Maximum (Marine Isotope Substage 5e [MIS 5e], 128-116 ka) is a distinctive event in recent Earth history. Shoreline successions of this age are important for calibrating climate models and defining the overall behaviour of the crust-mantle system to fluctuating ice and ocean water volumes. In a global context, the recently intensified interest in last interglacial shoreline successions has revealed considerable variability in the magnitude of sea level rise during this time interval and highlighted the need to examine palaeosea level evidence from tectonically stable, farfield settings. Situated in the far-field of continental ice sheets and on the tectonically stable Gawler Craton, the $300 \mathrm{~km}$ coastal sector of western Eyre Peninsula between Fowlers Bay and Lake Newland in southern Australia represents an important region for defining the glacio-eustatic (iceequivalent) sea level attained during the last interglacial maximum based on the relative sea level observations from this region. Low energy, shoaling upward, peritidal bioclastic carbonate successions of the last interglacial (locally termed Glanville Formation) formed within back-barrier, estuarine-lagoonal environments in the lee of aeolianite barrier complexes (locally termed Bridgewater Formation) along this coastline. The well-preserved shelly successions (coquinas) contain diverse molluscan fossil assemblages including species no longer living in the coastal 
waters of South Australia (e.g. the Sydney cockle Anadara trapezia and the benthic foraminifer Marginopora vertebralis). The extent of amino acid racemization (a measure of fossil age based on increasing D/L value) in a range of species, and in particular A. trapezia and Katelysia sp., confirms the time-equivalence of the isolated embayment fill successions, correlated with the informal type section of the Glanville Formation at Dry Creek, north of Adelaide. Preliminary U-series analyses on A. trapezia also suggest a correlation with the last interglacial maximum, but further highlight the complexity in dating fossil molluscs by the U-series method in view of their open-system behaviour. The shelly successions of the Glanville Formation occur at elevations higher than attained by sea level in the current, Holocene interglacial. A higher sea level of between $2.1 \pm 0.5$ to $4 \pm 0.5 \mathrm{~m}$ above present sea level (APSL) is inferred for the last interglacial maximum (MIS 5e) along this coastline based on the elevation of sedimentary successions host to the shallow subtidalintertidal fossil molluscs Katelysia sp., and Anadara trapezia. The palaeosea level observations place a lower limit on the sea level attained during the last interglacial maximum and suggest that caution be exercised in the definition of the upper limit of sea level during this interglacial.

\section{KEY WORDS: amino acid racemization, last interglacial sea-levels, Marine Isotope Sub-stage 5e, southern Australia, Quaternary molluscs, Uranium-series dating of molluscs}

\section{Introduction}

Interest in last interglacial (Marine Isotope Substage, MIS 5e; c. 128 to $116 \mathrm{ka}$ ) coastal sedimentary successions has intensified with the recognition that they provide important insights about relative sea-level changes in response to subtle variations in Earth surface temperatures, and may accordingly inform an understanding of sea-level changes in an enhanced Greenhouse Earth. Ocean surface waters along continental margins were warmer during the last interglacial, as attested by the extension in the latitudinal range of reef building corals and marine molluscs (Ludbrook 1984; Murray-Wallace \& Belperio 1991; Muhs, Simmons \& Steinke 2002, Muhs et al. 2012). Warmer sea surface temperatures enhance the magnitude of sea level rise due to steric effects (thermally and salinity-induced expansion of water volume), and an understanding of the magnitude of this phenomenon will inform models of future coastal landscape change (Hearty et al. 2007; Woodroffe \& Murray-Wallace 2012). Last interglacial coastal successions also represent important benchmarks for quantifying longer-term geodetic changes resulting from tectonism, as well as adjustments of the crust-mantle system in response to fluctuating ice and water (liquid state) 
volumes in glacial cycles (Dutton \& Lambeck 2012; Murray-Wallace \& Woodroffe 2014; Creveling et al. 2015).

Geophysical investigations have shown that relative sea levels inferred from specific sites on the Earth's surface may not necessarily represent a former eustatic (ice-equivalent) sea level at the time of deposition, as modern observations of palaeoshoreline datums may reflect the pre- and postdepositional history of crust-mantle adjustments that have accompanied ice and ocean volume changes (Lambeck, Purcell \& Dutton 2012). These effects are particularly compounded in some settings by the incomplete relaxation of the crust-mantle system at the time of sedimentation such as during the late last interglacial (MIS 5a, 85-80 ka) on the North American Atlantic Coastal Plain (Wehmiller et al. 2004). Collectively, the effects of isostatic processes are most evident in nearand intermediate-field sites to former ice sheets (Long et al. 2015). For example, palaeosea level observations for last interglacial successions on the northern Atlantic Coastal Plain of North America have been affected by the incomplete relaxation of the crust-mantle system following the penultimate glaciation (MIS 6), as well as adjustments that have occurred since the withdrawal of the Laurentide Ice Sheet following the Last Glacial Maximum (Lambeck, Purcell \& Dutton 2012).

The last interglacial maximum refers to the period classically defined from marine cores as MIS 5e (Shackleton 1969), and bracketed between c. 128 to $116 \mathrm{ka}$ ago based on the $\delta^{18} \mathrm{O}$ plateau within central North Atlantic marine core MD95-2042 (Shackleton et al. 2002) and the dating of relict coral reef facies (Muhs 2002). The last interglacial maximum has also been defined as a distinct single peak extending from 132 to $115 \mathrm{ka}$ within the Antarctic EPICA Dome C ice core, representing the warmest interval during the past $800 \mathrm{ka}$ (Masson-Delmotte et al. 2010). During the last interglacial maximum relative sea levels appear globally to have been higher than during the current, Holocene interglacial (Stirling et al. 1995; Muhs 2002; Schellmann \& Radtke 2004; Kopp et al. 2009; Dutton \& Lambeck 2012; O’Leary et al. 2013; Murray-Wallace \& Woodroffe 2014). Despite these observations, the definition of a eustatic (ice-equivalent) sea level has remained controversial. A de facto estimate of eustatic sea level for MIS 5e of $6 \mathrm{~m}$ above present sea level (APSL) was inferred from early compilations of relative sea level observations for the Pacific and Indian Oceans, which showed fossil corals between 2 and $9 \mathrm{~m}$ APSL in settings remote from active plate boundaries (Veeh 1966; Murray-Wallace \& Belperio 1991). Subsequent work in the northern Bahamas (Grand Bahamas and Abaco) identified prominent shoreline notches at $5.9 \mathrm{~m}$ APSL and U-series ages with a mean age of $125 \mathrm{ka}$ (Neumann \& Moore 1975) seemed to corroborate the $6 \mathrm{~m}$ APSL inferred eustatic sea level for MIS 5e. On this basis, subsequent investigations have used the $6 \mathrm{~m}$ value as a datum for quantifying rates of tectonic uplift in plate boundary settings (Broecker et 
al. 1968; Chappell 1974; Bloom et al. 1974 and many others since) for inferring the ages of older or younger reef terraces.

Subsequent investigations have revealed geographical variability at a global-scale in relative sea level for the last interglacial maximum, with observations tending to range between 3 to $9 \mathrm{~m}$ APSL (Hearty et al. 2007; Kopp et al. 2009; Dutton \& Lambeck 2012; Long et al. 2015). Relative sea levels during the course of the last interglacial maximum (MIS 5e) are likely to have varied systematically around the globe, as noted for the current, Holocene interglacial (e.g. an early highstand followed by a relative sea level fall in far-field sites, compared with a continuously rising sea level during the interglacial in intermediate-field sites; or a continuously falling relative sea level in formerly glaciated, near-field regions; Clark, Farrell \& Peltier 1978; Nakada \& Lambeck 1989; Lambeck \& Nakada 1992; Lewis et al. 2013). In addition, the preserved morphostratigraphy of sedimentary successions in different geographical settings may only chronicle short portions of the relative sea level record of the last interglacial maximum, explaining some of the additional variability in inferred palaeosea levels.

Estimates of glacio-eustatic sea level have commonly involved the assumption that eustatic sea level can be directly quantified from tectonically stable settings and that such estimates represent a direct measure of ice-equivalent sea level. Although estimates of glacio-eustatic sea level in far-field settings, remote from former continental ice sheets may provide a more accurate measure of ice-equivalent sea level, than near-field, intermediate-field, or tectonically-active settings, such estimates are still locally subject to the effects of glacial isostatic adjustment (GIA) processes (Milne \& Mitrovica 2008), as noted for Holocene coastal successions (Belperio, Harvey \& Bourman 2002; Lewis et al. 2013). In particular, the combined effects of continental levering (hydro-isostasy) and equatorial-ocean siphoning, involving forebulge collapse and withdrawal of water from equatorial regions to areas of former forebulges (Mitrovica \& Peltier 1991), are expressed as a slight, relative sea level fall following the attainment of the post-glacial highstand. The relevance of the Eyre Peninsula coastline for examining these issues is further evaluated.

In this work the magnitude of sea-level rise attained during the last interglacial maximum is evaluated based on the study of the Glanville Formation from western Eyre Peninsula (Figure 1). The paper contributes to the global problem of defining glacio-eustatic (ice-equivalent) sea level during the highstand event of the last interglacial maximum (MIS 5e). A series of marine embayment-fill and associated back-barrier estuarine-lagoonal shoreline successions of the Glanville Formation are examined for their palaeo-sea level record. Amino acid racemization (AAR), a measure of age, based on the increasing ratio of right-handed to left-handed amino acids in fossils (expressed as a $\mathrm{D} / \mathrm{L}$ value) is used to establish the time-equivalence of the coastal 
successions mapped as Glanville Formation, based on morphostratigraphical and biostratigraphical evidence. The AAR analyses are based on Reverse Phase, High Performance Liquid Chromatography (RP-HPLC) and build upon previous investigations using Gas Chromatography (Murray-Wallace 2000). Preliminary U-series analyses on the fossil mollusc Anadara trapezia are also reported. The inferred palaeosea levels are then compared with observations from last interglacial shoreline successions from other far-field locations to evaluate the findings of this study.

\section{Methods}

\section{Field observations}

Preserved Glanville and Bridgewater Formation bioclastic sediments were examined and systematically mapped along the west coast of Eyre Peninsula for $300 \mathrm{~km}$ from Fowlers Bay to Lake Newland (Figure 1). At selected sites specimens of fossil molluscs for amino acid racemization (AAR) and uranium-series analyses were collected by digging into natural cliff exposures and recently excavated borrow pits. Shell species were recorded as an aid to identifying palaeoenvironments, and where possible, constraining palaeosea level inferences. The sequences examined in this study are from correlative deposits of the late Pleistocene Glanville Formation as originally defined near the Adelaide coastline of Gulf St Vincent (Firman 1966; Ludbrook 1976; Cann 1978).

Where possible, molluscs for AAR analysis were collected from depths exceeding $1 \mathrm{~m}$ below the original ground surface to reduce the effects of high summer temperatures on diagenetic racemization. This sampling approach ensures that the thermal history experienced by the buried fossils reflects variations due to long-term climate change. The location of sample sites was recorded using a portable GPS. Geological sections were measured and surveyed to local bench marks by theodolite so that the palaeosea level indicators, in this case the fossil molluscan faunas and their associated facies, could be related to modern tidal datum. Uncertainty in survey data is approximately $\pm 5 \mathrm{~cm}$. However uncertainty in palaeosea level indicators may be much greater.

\section{Amino acid racemization}

Amino acid racemization (AAR) analyses were undertaken on fossil marine molluscs to confirm the time-equivalence of these shelly successions with the informal reference section of the last interglacial Glanville Formation at Dry Creek, north of Adelaide (Cann 1978). AAR analyses were undertaken on the hinge region of bivalve molluscs and the columella of gastropods. Analyses are for the total hydrolysable amino acids (inter-crystalline fraction) for the amino acids aspartic acid, 
glutamic acid, phenylalanine and valine. The degree of within-fossil and between-fossil variation in $\mathrm{D} / \mathrm{L}$ values was assessed by the preparation of up to six subsamples from each fossil shell sample. The pre-treatment cleaning procedure involved the physical removal of adhering calcium carbonate sediment from the shell surfaces using a dental drill, followed by the digestion of approximately one third of the total shell calcium carbonate (i.e. the outer, diagenetically-modified portion of the shells) in $8 \mathrm{~mol} / \mathrm{L} \mathrm{HCl}$. AAR samples were subsequently digested and hydrolysed for 22 hours at $110^{\circ} \mathrm{C}$ in $7 \mathrm{~mol} / \mathrm{L} \mathrm{HCl}$. Samples were rehydrated with a solution containing $0.01 \mathrm{M} \mathrm{L}-$ homoarginine. Following hydrolysis, the amino acids underwent pre-column derivatization using $o$-phthaldialdehyde (OPA) together with the chiral thiol, $N$-isobutyryl-L-cysteine (IBLC) to yield fluorescent diastereomeric derivatives of the chiral primary amino acids. Amino acid D/L values were determined on peak area calculations and analytical precision is typically $\leq 3 \%$. AAR measurements were undertaken using an Agilent 1100 Reverse Phase, High Performance Liquid Chromatograph (RP-HPLC) with a Hypersil C-18 column and auto-injector, following the analytical methods set out in Kaufman \& Manley (1998).

\section{$U$-series dating}

Uranium-series dating of the fossil bivalve mollusc Anadara trapezia was undertaken by laser ablation multi-collector ICP-MS at the Wollongong Isotope Geochronology Laboratory, University of Wollongong. The genus Anadara was selected as the fossil shell valves are commonly very thickly developed $(5-10 \mathrm{~mm})$ offering the potential for a protective microenvironment to the postmortem uptake of uranium. Well-preserved fossil specimens were analysed from Fowlers Bay (sample EP\#2; Figure 2a) and from Lake Newland (Figure 1). Laser ablation was undertaken with a New Wave Research $193 \mathrm{~nm}$ ArF excimer laser, equipped with a TV2 cell. Cut and polished shells were ablated with laser pulse rates of $5 \mathrm{~Hz}$ and a fluence of $5 \mathrm{~J} / \mathrm{cm}^{2}$. Spot analyses $(150 \mu \mathrm{m}$ spot size) were carried out by drilling each hole for a period of 60 seconds and the signal was then averaged over a period of 50 seconds. Helium was used as a carrier gas at a flow rate of 0.6 L/minute. Thorium $\left({ }^{230} \mathrm{Th},{ }^{232} \mathrm{Th}\right)$ and Uranium $\left({ }^{234} \mathrm{U},{ }^{235} \mathrm{U},{ }^{238} \mathrm{U}\right)$ isotopes were measured on a Thermo Neptune Plus multi-collector ICP-MS. All five isotopes were collected in static mode, with ${ }^{230} \mathrm{Th}$ and ${ }^{234} \mathrm{U}$ collected in ion counters. Helium flow rate and plasma parameters were tuned with NIST610 element standard to derive a ${ }^{232} \mathrm{Th} /{ }^{238} \mathrm{U}$ ratio for this standard greater than 0.8 and minimise differences in fractionation between Th and U (Bernal et al. 2005).

In the absence of a matrix-matched, measured ${ }^{234} \mathrm{U} /{ }^{238} \mathrm{U}$ and ${ }^{230} \mathrm{Th} /{ }^{238} \mathrm{U}$ isotopic ratios were corrected for elemental fractionation and Faraday cup/SEM yield by comparison with BCR-2G 
basaltic glass provided by the United States Geological Survey. Hoffmann et al. (2007) measured $\left({ }^{230} \mathrm{Th} /{ }^{238} \mathrm{U}\right)$ activity ratios of $1.0043 \pm 0.0033$ and $\left({ }^{234} \mathrm{U} /{ }^{238} \mathrm{U}\right)$ of $1.0049 \pm 0.0012$ in this material (parentheses denote activity ratios throughout this article). Although these values were obtained on powders, and the isotopic ratios of the glass could differ from these values (but in principle, they should not). Concentrations of $\mathrm{U}$ and Th were determined using NIST610 as a reference and checked for accuracy with NIST612. Calculated Th concentrations deviated on average by up to $7 \%$ from the certified value, and $U$ concentration by up to $9.7 \%$.

Eleven laser ablation spots were produced in an analytical transect from the umbo to the outer growth edge of each of the Anadara trapezia samples (i.e. perpendicular to the shell's surface). Closed-system ${ }^{230} \mathrm{Th}$ ages and initial $\left({ }^{234} \mathrm{U} /{ }^{238} \mathrm{U}\right)$ were calculated from corrected $\left({ }^{230} \mathrm{Th} /{ }^{238} \mathrm{U}\right)$ and $\left({ }^{234} \mathrm{U} /{ }^{238} \mathrm{U}\right)$ ratios using IsoPlot (Ludwig 2003).

\section{Geological and geotectonic setting of the Glanville Formation, Eyre Peninsula}

\section{Physical landscape setting}

The western coastline of Eyre Peninsula trends northwest-southeast and is highly embayed, resulting from the structural control by outcrops of Archaean and Paleoproterozoic metasediments, metavolcanics, granitoids and Pleistocene aeolianites of the Bridgewater Formation (Flint 1987, 1992; Rankin \& Flint 1991; Parker 1993; Short \& Woodroffe 2009; Bourman, Murray-Wallace \& Harvey 2016). The field sites extend along some $300 \mathrm{~km}$ of coastline from Fowlers Bay southeast to Lake Newland (Figure 1). The smaller embayments attain shore-parallel lengths of up to $10 \mathrm{~km}$. The modern/Holocene embayments have broad openings to the Great Australian Bight, have no fluvial input and do not experience tidal attenuation common to highly constricted estuaries. In a similar manner, changes in tidal range within the region at the time of deposition of the Glanville Formation is unlikely in view of the size and typical water depths of these open coastal embayments. The morphostratigraphic context of the late Pleistocene successions suggests a comparable physical landscape setting at the time of their deposition to the modern coastal landscapes.

The modern coastline of western Eyre Peninsula is dominated by barrier complexes comprising unconsolidated Holocene transverse and parabolic dunes that typically extend up to 20 $\mathrm{m}$ above present sea level (APSL) and up to $2 \mathrm{~km}$ inland from the coast. Actively eroding sea cliffs developed on Pleistocene aeolianite also characterise this coastline. Older aeolianite successions occur along this coastline with two characteristic forms of facies architecture. Along some coastal sectors the consolidated aeolianites comprise multiply stacked aeolian sand bodies that display welldeveloped tabular cross-stratification representing the slip-faces of advancing coastal dunes. The 
successions commonly have interbedded palaeosols. These aeolianite complexes, which unconformably overlie Archaean to Paleoproterozoic crystalline bedrock attain vertical thicknesses of 20 to $150 \mathrm{~m}$ giving rise to prominent coastal cliffs (e.g. Whaler's Way). Elsewhere (e.g. Fowlers Bay), physically well-defined individual coastal barriers have developed in former bedrockconstrained, open marine embayments and represent prograded sequences of barriers related to successive Pleistocene interglacials (Belperio 1988; Belperio, Murray-Wallace \& Cann 1995; James \& Bone 2011). The late Pleistocene embayment-fill successions comprise relict subtidal and peritidal facies and associated aeolian dune (aeolianite) barrier shoreline complexes. They are situated landward of an equivalent Holocene coastal barrier succession (Belperio, Gostin, Cann \& Murray-Wallace 1988).

The Chandada Plains, a gently undulating landscape of calcreted Pleistocene aeolian dunes of the Bridgewater Formation, without well-defined surface drainage, occurs landward of the late Pleistocene and Holocene coastal successions (Twidale \& Campbell 1985; Figure 1). The calcareous sand of the Chandada Plains was derived principally from the continental shelf and brought inland by the dominant westerly winds throughout the Pleistocene.

Older basement rocks underlying the late Pleistocene sedimentary successions comprise the Wilgena and Nuyts Subdomains of the Gawler Craton, a region of long stability of Archaean to Paleoproterozoic crystalline basement rocks (granites and gneisses) that have remained undeformed since $1450 \mathrm{Ma}$ (Parker 1993; Hand, Reid \& Jagodzinski 2007). The Sleaford Complex (2.7-2.3 Ga) is the dominant bedrock within the region, comprising contorted and compositionally well-banded gneisses (Parker, Fanning \& Flint 1985; Parker 1993). These basement rocks are intruded by Hiltaba Suite granites (1580 Ma; U/Pb age) which crop out along some of the prominent headlands (e.g. Calca Peninsula) and granites of the Lincoln Complex (1620 $\pm 4 \mathrm{Ma}$; U/Pb age) at Murat, Bosanquet and Decres Bays and Point Brown (Parker 1993; Figure 1).

Situated on the Gawler Craton, western Eyre Peninsula is one of the geologically most stable areas in Australia characterised by minimal seismic activity, (Clark \& Leonard 2003; Braun et al. 2009), high flexural rigidity $\left(6.9 \times 10^{24} \mathrm{~N}\right.$; Zuber, Bechtel \& Forsyth 1989), and a depth of 40 $\mathrm{km}$ to the Mohorovičić discontinuity (Clitheroe et al. 2000). The Gawler Craton is also characterised by a small value of post-Jurassic total crustal extension (Kharazizadeh et al. 2016), further signifying the long-term tectonic stability of the region. Regional-scale faults are concentrated to the east of the study area, along the eastern portion of Eyre Peninsula and are expressed morphologically as well-defined fault scarps (e.g. Lincoln Fault which largely defines the eastern coastline of the peninsula; Twidale \& Campbell 1985; Bourman, Murray-Wallace \& Harvey 2016). 
The open ocean coastline of western Eyre Peninsula adjoins a low gradient continental shelf of the Eastern Great Australian Bight with the middle neritic zone up to $150 \mathrm{~km}$ wide as defined by the $100 \mathrm{~m}$ isobath (James \& Bone 2011). It is a high energy, wave-dominated system with winter storm swells and lower energy swells continuing through summer. Swell periods are typically 1014 seconds with wave heights attaining 2-3 m and wave lengths reaching up to $200 \mathrm{~m}$ (Short \& Hesp 1982; Short 2004). Tides are micro-tidal and semi-diurnal reaching up to a maximum of approximately $2 \mathrm{~m}$ in the open ocean embayments within the study area (Bureau of Meteorology, 2015). In terms of palaeosea level estimation, present mean sea level (MSL) is $1 \mathrm{~m}$ above low water datum (LWD) at Ceduna, Mean High Water Spring Tide (MHWST) $1.67 \mathrm{~m}$, Mean High Water Neap Tide (MHWNT) $1.08 \mathrm{~m}$ and Lowest Astronomical Tide -0.01 m (Marine and Harbors, 1994; Belperio, Harvey \& Bourman 2002). The region experiences a dry Mediterranean to semiarid style climate with hot dry summers and cool wet winters. Average annual rainfall recorded at Ceduna (1939-2015) is $296 \mathrm{~mm}$ per annum and summer evaporation far exceeds rainfall. Present day yearly evaporation ranges between 2000 to $2400 \mathrm{~mm}$ at Ceduna (Australian Climate Averages). Current mean annual temperature, a relevant consideration for the interpretation of the amino acid racemization data in this study ranges from $16.5^{\circ} \mathrm{C}$ at Elliston to $17.6^{\circ} \mathrm{C}$ at Streaky Bay (Australian Climate Averages).

\section{The Glanville Formation}

Since the early observations of Woods (1862; later publishing as Tenison-Woods) and Tate (1879) of shelly limestones cropping out along extensive sectors of the southern Australian coastline and representing an 'upheaval of the land' (Tate 1879, p. lxviii), many have documented the field relationships of site specific occurrences of lithologically and palaeontologically similar successions. Reviews of these early studies are provided elsewhere (Ludbrook 1984; MurrayWallace \& Belperio 1991; Belperio, Murray-Wallace \& Cann 1995).

Sediments of what is now termed the Glanville Formation (Firman 1966) were first described in the Adelaide region of Gulf St. Vincent in an excavation for a graving dock at Glanville (Howchin 1888). Within the depth interval 10.05 to $11.27 \mathrm{~m}$ below the ground surface, the section revealed calcareous sand with a diverse molluscan fauna beneath a calcreted subaerially exposed surface. Most of the fossil marine mollusc species are represented by modern equivalents, but the presence of some species no longer extant in the coastal waters of South Australia, led several researchers to describe the faunal assemblages variously as 'Sub-Recent' or 'Sub-fossil' (Tate 1879; Howchin 1888; Ludbrook 1984). 
Several species within the Glanville Formation represent a southerly extension in their latitudinal range associated with warmer inner shelf waters and include the Sydney Blood cockle Anadara trapezia and the bivalve Mactra eximia, the Shark Bay pearl oyster Pinctada carchariarum, the conical-fusiform gastropod Euplica bidentata, and the megascopic, benthic foraminifer Marginopora vertebralis (Murray-Wallace et al. 2000). Solitary specimens of the coral Goniopora somaliensis have also been identified which today are restricted to the north of Moreton Bay, southern Queensland, and Ningaloo Reef, Western Australia (Daniel 2002). These fauna relate to an enhanced Leeuwin Current during the last interglacial maximum, bringing warmer, lower salinity ocean surface waters from the Indonesian Archipelago and the eastern Indian Ocean to the inner continental shelves of south-western and southern Australia (Cann \& Clarke 1993; McGowran et al. 1997; Murray-Wallace et al. 2000; Wyrwoll et al. 2009). Sediments of the Glanville Formation are characteristically capped by an indurated and laterally persistent calcrete horizon (subaerial exposure surface) displaying a variety of micromorphologies. The calcrete effectively protects the underlying succession from denudation (Firman 1966; Ludbrook 1976; Cann 1978).

The last interglacial age (c. 128 to $116 \mathrm{ka}$ ) of the Glanville Formation has been established based on a geographically widespread series of studies. U-series measurements on the fossil molluscs Anadara trapezia, Ostrea sp., Katelysia sp. and Turbo sp. yielded an age of $125 \pm 20 \mathrm{ka}$ and aragonitic muds, $100 \pm 30 \mathrm{ka}$, all from back-barrier estuarine-lagoonal facies of the Woakwine Range, a prominent coastal barrier of the Coorong Coastal Plain in southern South Australia (Schwebel 1978; 1984). U-series measurements by laser ablation, multi-collector inductively coupled plasma mass spectrometry (MC-ICP-MS) derived an age of $120 \pm 10 \mathrm{ka}$ on the outer growth edge of robust specimens of Anadara trapezia from Tourville Bay, Eyre Peninsula (Eggins et al. 2005). A U-series age of $124 \pm 9 \mathrm{ka}$ on the solitary coral Goniopora somaliensis was also reported by Daniel (2002) from an outcrop of the Glanville Formation at Flagstaff Landing, Streaky Bay. In addition, thermoluminescence (TL) dating of fine and coarse grained quartz sand from correlative peritidal sediments from a marine vibracore in northern Spencer Gulf (Core SG\#182) yielded ages of $90 \pm 15 \mathrm{ka}$ and $96 \pm 24$ ka respectively, and were correlated with the last interglacial maximum (Belperio et al. 1984). Subsequent TL analyses from aeolian facies of the Woakwine Range, yielded several ages falling between $132 \pm 6$ ka to $117 \pm 8$ ka (Huntley, Hutton \& Prescott 1993, 1994; Banerjee et al. 2003; Murray-Wallace et al. 1999). Critically, these aeolian facies interfinger and are coeval with back-barrier, estuarine-lagoonal facies in which Katelysia sp., yielded amino acid D/L values consistent with a last interglacial age (see photographs in Murray-Wallace et al. 1999). Amino acid racemization has also been used extensively to establish the time equivalence of last 
interglacial peritidal facies of the Glanville Formation in southern Australia (Murray-Wallace 2000).

Along the geotectonically highly-stable, open ocean coastline of western Eyre Peninsula, the Glanville Formation occurs as estuarine-lagoon facies that developed in the lee of contemporaneous barrier-dune complexes. The barrier successions comprise transgressive parabolic dunes developed on transverse dunes as well as relict foredunes (beach ridges), the former having dune crests up to $20 \mathrm{~m}$ APSL. The coastal barriers are up to $2 \mathrm{~km}$ wide in shore-normal cross-section and on their leeward sides, interfinger with their coeval lagoonal facies (Belperio, Murray-Wallace \& Cann 1995). The aeolian sediments (aeolianites) have been mapped as Bridgewater Formation (Belperio 1995) and have been instrumental in protecting the back-barrier, estuarine-lagoonal facies of the Glanville Formation from coastal erosion in the current Holocene interglacial. The Bridgewater Formation which extends from western Victoria, where it was first defined at Bridgewater Bay (Boutakoff 1963), to western South Australia refers to Pleistocene aeolian facies of coastal barriers comprising large-scale tabular and trough cross-bedded bioclastic sand. The formation is exposed in many of the coastal cliffs of South Australia (e.g. southern Eyre and Yorke Peninsulas, Kangaroo Island and portions of Fleurieu Peninsula; Wilson 1991; Lachlan 2011) as well as the sector of coast from the Murray Lakes region and Hindmarsh Island, south-southeast to Port MacDonnell (Sprigg 1952; Belperio 1995; Murray-Wallace et al. 2010; Blakemore, Murray-Wallace \& Lachlan 2014, Blakemore, Murray-Wallace, Westaway \& Lachlan 2015). The successions provide evidence for multiple generations of development based on the presence of unconformities and interbedded palaeosols.

\section{Molluscan faunas and palaeoenvironments of the Glanville Formation, western Eyre Peninsula}

Back-barrier, estuarine-lagoonal facies of the late Pleistocene Glanville Formation on western Eyre Peninsula preserve diverse molluscan faunal assemblages (Table 1). The fossil molluscs are very well preserved due to the region's arid climate. A distinctive feature of the fossil assemblages is the generally larger size attained by many of the adult molluscs compared with the present Holocene interglacial. Another noteworthy feature is the widespread occurrence of the cockle Anadara trapezia and the benthic foraminifer Marginopora vertebralis which no longer live along much of the southern Australian coastline, having become locally extinct after the last interglacial maximum (MIS 5e) (Cann \& Clarke 1993; Murray-Wallace et al. 2000). A. trapezia (Deshayes 1840) is a eurythermal, estuarine, filter-feeding, shallow-burrowing bivalve of semi-infaunal habit. It is typically associated with stable, soft, fine textured substrates ranging from fine sand to silt and mud. In life position, the posterior portion of the shell is exposed above the sediment substrate. $A$. 
trapezia frequents the upper-most subtidal to intertidal portions of mudflats in protected estuarine environments.

The cockle Katelysia also occurs abundantly within these sedimentary successions. The genus lives gregariously in protected, intertidal sandflat environments (Ludbrook 1984; Harte 1998). Katelysia individuals frequent shallow water, protected estuaries, and are commonly the dominant mollusc represented (Nielsen 1964; Roberts 1984) forming coquina-like deposits dominated by their shells. Katelysia scalarina characteristically occurs in intertidal to shallow subtidal settings, while $K$. rhytiphora tends to favour shallow subtidal waters immediately below the low water limit of the intertidal zone to a depth of approximately $1 \mathrm{~m}$ below low tidal datum.

The turreted gastropod Batillaria (Zeacumantus) diemenensis is also common in these successions. The species grazes just below the sediment-water interface on sand and mudflats and occurs most prolifically in intertidal environments (Macpherson \& Gabriel 1962; Ludbrook 1984). Fossil molluscs found within the Glanville Formation sediments of western Eyre Peninsula are documented in Table 1. Collectively they indicate a shallow water depositional environment with a maximum water cover of less than $2 \mathrm{~m}$ within intertidal sandflat to shallow subtidal environments.

\section{Field sites, geochronological samples and inferred palaeosea levels}

\section{Fowlers Bay}

Situated at the western limit of the study area, Fowlers Bay is a $20 \mathrm{~km}$ long embayment facing south to the Southern Ocean (Figure 1). Four individual barrier shoreline complexes have previously been identified in the area based on morphostratigraphy (e.g. well-defined barrier shoreline-dune complexes in the regional landscape, contrasting degrees of sediment diagenesis, and interpretation of sedimentary facies from drill core; Belperio 1988; Figure 2a,b). Barriers include a modern/Holocene barrier and associated back-barrier estuarine-lagoonal (gypseous) facies, a well-defined last interglacial barrier and two older barrier-lagoonal complexes of presumed middle Pleistocene age (Belperio 1988; Belperio, Murray-Wallace \& Cann 1995). The last interglacial Glanville Formation occurs as a well-defined north to northeasterly-trending backbarrier, estuarine-lagoon facies that extends $6 \mathrm{~km}$ inland from the leeward edge of its associated barrier, and up to $13 \mathrm{~km}$ from the modern coastline in a series of depressions that trend parallel with the older barrier structures (Figures $2 \& 3$ ). A $2 \mathrm{~km}$ wide former seaway led to the marine flooding of pre-existing landscape depressions associated with four calcreted beach ridges of an older barrier complex that predate the last interglacial maximum. In each case, the lagoon facies landward of each relict beach ridge in this older barrier complex is approximately $0.5 \mathrm{~km}$ wide (Figure $2 \mathrm{a}$ ). 
Fossil specimens for AAR analysis were collected from two locations at Fowlers Bay (Figures 2a and 4; Table 2). Sample EP\#2 (Anadara trapezia and Katelysia rhytiphora) was collected from relict lagoonal sand flat facies on the landward side of a calcreted aeolianite barrier 7 $\mathrm{km}$ inland from the settlement of Fowlers Bay and the modern coastline (Figure 2a). Shells collected at this site for AAR and U-series analyses were from a depth of $1 \mathrm{~m}$ below the ground surface, although the shelly facies continues up profile to the modern land surface. The second sample, EP\#6 (Anadara trapezia) was collected from shelly lagoonal facies $5 \mathrm{~km}$ to the north of EP\#2 from sediments of similar lithological and palaeontological character, from a $1 \mathrm{~km}$ wide lagoonal infill between two calcreted aeolianite barrier ridges of the Lower Bridgewater Formation (Figure 2a,b). Articulated and in situ specimens of particularly robust A. trapezia (10 mm thick shell valves in their central growth areas and up to $65 \mathrm{~mm}$ along their hinge lines), characteristically in their semi-infaunal (biocenose) environmental context, were collected from a calcreted pavement on the seaward side of an older and more prominent aeolianite ridge that extends up to $10 \mathrm{~m}$ APSL. In this locality the fossil molluscs were only shallowly buried to a depth of $20 \mathrm{~cm}$ and occurred within a restricted area closer to the seaward margin of the barrier structure. Elsewhere and over most of the $1 \mathrm{~km}$ wide sandflat, the cockle Katelysia sp., represents the dominant mollusc and signifies slightly deeper water conditions at the time of deposition. The presence of sandflat facies on the seaward side of the older barrier implies that these sediments are younger and formed during a sea level highstand unrelated to the barrier structure.

The upper bounding surface of the relict lagoonal sandflat facies at Fowlers Bay extends up to $0.16 \mathrm{~m}$ above present sea level (APSL) at site EP\#2 and $0.15 \mathrm{~m}$ below present sea level $(0.15 \mathrm{~m}$ BPSL) at site EP\#6. Approximately $10 \mathrm{~km}$ east of site EP\#6, the same lagoonal sandflat facies extends up to $0.6 \mathrm{~m}$ APSL and at least $1.6 \mathrm{~m}$ above LWD (Figure 2a). Based on the presence of Katelysia rhytiphora and assuming a maximum water cover of $1.5 \pm 0.5 \mathrm{~m}$ reflecting the characteristic growth conditions of the species at the time of deposition implies a palaeosea level of up to $2.1 \pm 0.5 \mathrm{~m}$ at Fowlers Bay. The variability in the surface elevation of the relict intertidal facies over distances of several kilometres reflects natural variation in the original depositional surface topography and in places may reflect minor surface deflation. The presence of a strongly indurated calcrete on the top of the Glanville Formation, however, suggests minimal erosional deflation of the formation.

\section{Tourville Bay}

Situated approximately $100 \mathrm{~km}$ east of Fowlers Bay, Tourville Bay is a south-easterly-facing embayment with an entrance approximately $5 \mathrm{~km}$ wide, with the bay shoreline extending some 10 
$\mathrm{km}$ inland from the open ocean coastline (Figure 1). It is the most westerly of a series of embayments that from west to east include Tourville, Murat, Denial, Decres, Laura and Smoky Bays (Figure 1). Tourville Bay is protected from the full force of the Southern Ocean by a peninsula of Holocene dunes resting on bedrock on its southern margin and St Peter Island, part of the Nuyts Archipelago (Figure 1). The bay is fringed by relict sandflats of last interglacial age, Holocene coastal dunes, sandflats and mangrove woodlands.

Fossil molluscs for AAR analysis were collected at a depth of $0.5 \mathrm{~m}$ below the former land surface from relict sandflat facies of the Glanville Formation exposed within a borrow pit on the western side of Tourville Bay, some $300 \mathrm{~m}$ landward from the modern shoreline (Figure 1; Table 2). The faunal assemblage contains particularly well-preserved, articulated and in situ fossil molluscs dominated by Katelysia sp. Other molluscs present within the assemblage include Pinna bicolor, Brachidontes rostratus, Pecten sp. Numerous rhodoliths and the foraminifer Marginopora vertebralis and disarticulated Anadara trapezia are also present. The upper bounding surface of the relict intertidal facies occurs at $2.55 \mathrm{~m}$ APSL and implies a palaeosea level of at least this amount. The presence of $K$. rhytiphora which commonly frequents shallow subtidal waters immediately below the low water limit of the intertidal zone may imply a palaeosea level closer to $4 \pm 0.5 \mathrm{~m}$ APSL at the time of deposition.

\section{Denial Bay}

As a geographical feature, Denial Bay includes the southward facing bays of Murat Bay and Bosanquet Bay, between Cape Beaufort and Cape Vivonne (Figure 1). The Glanville Formation occurs along the western shorelines of Denial and Murat Bays, exposed within laterally-persistent but subdued coastal cliff exposures that extend up to $3 \mathrm{~m}$ above mean high water neap tides. A 3.4 $\mathrm{m}$ high cliff to the south of the township of Denial Bay reveals two superposed calcretes, one predating the Last Interglacial and a younger calcrete developed on a shell bed of presumed last interglacial age. Samples for AAR analysis were collected from $30 \mathrm{~cm}$ thick shell bed comprising a transported (thanatocenose) assemblage of fossil molluscs dominated by disarticulated Katelysia rhytiphora and $K$. scalarina that crops out in the upper-most portion of the coastal cliff. The upper bounding surface of the shell bed occurs $2.9 \mathrm{~m}$ above mean high water neap tide level (i.e. $3.98 \mathrm{~m}$ above LWD or $2.9 \mathrm{~m}$ APSL). Only one specimen of disarticulated A. trapezia was found within the deposit. A palaeosea-level of at least $3 \mathrm{~m}$ APSL is therefore inferred from this locality, but most likely represents a higher energy, storm-influenced facies due to the transported nature of the shelly assemblage. Accordingly, palaeosea level could not be confidently determined from this site. 


\section{Cape Thevenard}

Near Ceduna, Cape Thevenard trends south-westerly into Denial Bay and separates Murat and Bosanquet Bays (Figure 1). The cape has formed on deeply weathered bedrock overlain by aeolianites of the Bridgewater Formation up to $20 \mathrm{~m}$ thick. At Cape Thevenard on the south-eastern side of Murat Bay a $2.7 \mathrm{~m}$ high cliff reveals a $30 \mathrm{~cm}$ thick veneer of Glanville Formation resting unconformably on pedogenically-modified cross-bedded skeletal carbonate sand (aeolianite) of the Bridgewater Formation. The Glanville Formation sediment is represented by a pisolitic to nodular calcrete with fossil marine molluscs between calcrete nodules (e.g. A. trapezia, Katelysia sp.). The shells are strongly abraded, partly through transportation before deposition and subsequent diagenetic modification during calcrete development. The upper bounding surface of the succession occurs $2.9 \mathrm{~m}$ APSL but the shelly unit most likely represents a storm-reconcentrated deposit and accordingly is not a reliable palaeosea level indicator.

\section{Smoky Bay}

Smoky Bay is a north-northwesterly-trending, broadly linear embayment up to $22 \mathrm{~km}$ long backed by low bluffs of aeolianite of the Bridgewater Formation and foredune and dune sand of the Holocene St Kilda Formation (Rankin \& Flint 1991). The south-eastern portion of the bay is protected by Eyre Island, part of a truncated Holocene spit (Figure 1).

A borrow pit $13 \mathrm{~km}$ north-east of Point Brown (Figure 1) reveals sandflat facies of the Glanville Formation resting unconformably on a strongly indurated calcrete showing lithological characteristics of the calcretes commonly formed on the early Pleistocene Lower Bridgewater Formation (e.g. profile thickness and degree of induration). The faunal assemblage is dominated by extremely well-preserved Katelysia rhytiphora and Katelysia scalarina (articulated and disarticulated individuals) and the gastropod Batillaria (Zeacumantus) diemenensis. Both genera are represented by large individuals indicating a highly productive environment. Other common faunal elements include Tellina deltoidalis, A. trapezia and Bulla botanica. Specimens of Katelysia rhytiphora, A. trapezia, Batillaria sp., and Bulla botanica were collected for AAR analysis. The fossil molluscs indicate a protected sandy mud flat environment within an estuarine embayment at the time of deposition. The upper bounding surface of the Glanville Formation at this locality occurs at $1.9 \mathrm{~m}$ APSL indicating a higher sea level of at least this amount at the time of deposition. Based on the composition of the molluscan fossil assemblage, dominated by the intertidal to shallow subtidal species Katelysia scalarina and K. rhytiphora, a higher sea level of up to $3.4 \pm 0.5$ $\mathrm{m}$ is inferred. 


\section{Lake Newland}

Lake Newland comprises two prominent, elongate lakes as well as several minor lakes that trend broadly north-south (Figure 1). The location of Lake Newland and Anxious Bay may in part be structurally controlled, as it coincides with the Polda Basin, an east-west trending graben (Flint, 1992). The lake system is protected from the high wave energy of the Great Australian Bight by a 2 km wide coastal barrier complex of predominantly Holocene dune sediments mapped as Semaphore Sand (Flint 1992).

Sandflat facies as part of a late Pleistocene back-barrier estuarine-lagoon complex occur at Lake Newland, $32 \mathrm{~km}$ south-southeast of Port Kenny (Figure 1). The sample site is a borrow pit on the eastern side of the southern major lake. The $1 \mathrm{~m}$ deep excavation has largely removed the calcrete horizon developed on the upper-most portion of the Glanville Formation to reveal an abundant fossil molluscan fauna dominated by very well-preserved A. trapezia and Katelysia sp. The upper-bounding surface of the calcreted lagoon facies extends up to $2 \mathrm{~m}$ APSL and implies a higher sea level by at least that amount during the last interglacial. A maximum water cover of $1.5 \pm 0.5 \mathrm{~m}$ based on the abundant presence of Katelysia sp., would imply a sea level of $3.5 \pm 0.5 \mathrm{~m}$ at the time of deposition. Samples for AAR and U-series analyses were collected from below the calcrete horizon (Table 2).

In summary, the Glanville Formation was examined at six sites along a $300 \mathrm{~km}$ coastal sector of western Eyre Peninsula. The fossiliferous successions at Fowlers Bay, Tourville Bay, Smoky Bay and Lake Newland contain the best preserved in situ (biocenose) molluscan faunal assemblages. The sedimentary successions and their contained faunas formed in intertidal to shallow subtidal depositional environments, and accordingly, represent the most reliable palaeosea level information. In contrast, the successions at Denial Bay and Cape Thevenard contain transported (thanatocenose) molluscan fossil assemblages yielding less reliable palaeosea level information.

\section{Holocene St Kilda Formation}

Fossil molluscs for AAR analyses were also collected from the Holocene St Kilda Formation to compare with the results from the late Pleistocene Glanville Formation. The St Kilda Formation is a succession of shelly sands deposited in equivalent sedimentary environments and seaward of the Glanville Formation but under a lower sea level than attained during the last interglacial maximum (MIS 5e). The St Kilda Formation as re-defined by Cann \& Gostin (1985) refers to coastal sediments deposited since the culmination of the post-Last Glacial marine transgression, which in southern Australia was attained by 7000 years ago (Lewis et al. 2013). 
On western Eyre Peninsula the St Kilda Formation abuts the last interglacial Glanville Formation and is well preserved as a prograded sequence within the large marine embayments. The upper surface of the formation tends to be topographically lower than equivalent sediments of the last interglacial Glanville Formation. Fossil molluscs were collected from an excavation through the most landward Holocene chenier at Tourville Bay near the last interglacial sample site. The chenier was up to $0.5 \mathrm{~m}$ high and rested on a Holocene mudflat.

At Decres Bay $10 \mathrm{~km}$ south-east of Ceduna, Holocene fossil molluscs were collected from a coquina exposed in a drainage trench located near the landward limit of the St Kilda Formation and adjacent to a late Pleistocene calcreted aeolianite. The fossil assemblage was dominated by articulated bivalves Katelysia scalarina and Spisula (Notospisula) trigonella and the gastropod Batillaria (Zeacumantus) diemenensis.

At Streaky Bay articulated and well-preserved Katelysia sp., shells were collected for AAR analyses from a Holocene sandflat facies adjacent to Highway 1 and about $1 \mathrm{~km}$ inland from the modern coastline. The shelly succession is dominated by Katelysia scalarina, Spisula (Notospisula) trigonella and Batillaria (Zeacumantus) diemenensis. The landward feather-edge of the sandflat is backed by coastal dunes.

On the eastern shoreline of Baird Bay adjacent Baird Bay Road, Holocene shelly sands dominated by Katelysia rhytiphora and K. scalarina crop out and signify a slightly larger Baird Bay in the middle Holocene. Numerous Katelysia sp., show the effects of mechanical abrasion and bioerosion. Other molluscs present include Brachidontes erosus, Mactra australis and turreted gastropod Batillaria (Zeacumantus) diemenensis.

\section{Results}

\section{Amino acid racemization analyses}

The relative extents of racemization for aspartic acid (ASP), glutamic acid (GLU), phenylalanine (PHE) and valine (VAL) within the Pleistocene and Holocene fossil molluscs varied slightly with age, reflecting progressive changes in racemization rate for the different amino acids with time. In the late Pleistocene molluscs, the relative extents of racemization generally conformed to PHE $\geq A S P>G L U>V A L$ (Table 2). Aspartic acid and phenylalanine are the fastest racemizing amino acids. The higher D/L values for PHE in the late Pleistocene shells reflect an increase in rate of racemization relative to ASP in late diagenesis. In the Holocene molluscs the relation followed ASP $>$ PHE $>$ GLU $>$ VAL, while in the modern specimens the relation ASP $>$ GLU $>$ PHE $>V A L$ was noted and in accord with previous observations (Lajoie, Wehmiller \& Kennedy 1980; Table 3). 
The extent of amino acid racemization (total hydrolysable amino acids) in the fossil molluscs from the late Pleistocene and Holocene coastal successions, and modern specimens, is consistent with their relative ages and with $\mathrm{D} / \mathrm{L}$ values based on reverse phase, high performance liquid chromatography, previously reported from similar stratigraphical contexts elsewhere in southern Australia (Murray-Wallace et al. 2010; Tables 2 and 3). The comparable extent of amino acid racemization in the fossil molluscs from each of the sedimentary successions mapped as Glanville Formation on western Eyre Peninsula confirms their time equivalence, and that they represent correlatives to the type section of the Glanville Formation at Dry Creek on the Adelaide Plains (Figure 5, Table 4).

Fossil mollusc species not previously analysed by AAR (Conus anemone, Batillaria sp., Bulla botanica, Penion mandarinus and Fusinus australis) show comparable extents of racemization to the other late Pleistocene specimens illustrating their geochronological potential.

\section{$U$-series analyses}

The ${ }^{230} \mathrm{Th} /{ }^{232} \mathrm{Th}$ activity ratios in the shells analysed showed high values (the lowest value was 55 ) suggesting that a detrital correction is not required (Table 5). Shells of marine molluscs are known to be problematic for U-series dating because of their open-system behaviour involving uranium uptake during diagenesis (Szabo \& Rosholt 1969; Kaufman et al. 1971; Eggins et al. 2005). This phenomenon can be tested using laser ablation, by investigating how uranium concentrations vary across the internal profile of shells. In sample E103 (Lake Newland), uranium mobility is clear, with a strong gradient in concentrations across the transect within the shell (Figure 6a). Optical analysis suggests that different generations of the shell had formed between the three deepest spots and the rest of the shell. For the eight shallower spots, uranium concentrations peak in the middle of the transect, possibly suggesting leaching of uranium (Pike \& Hedges 2002). Although the validity of the determined closed-system ${ }^{230}$ Th ages is questionable, the ages range from $103 \pm 3$ to $124 \pm 4 \mathrm{ka}$ (1-sigma uncertainty). Within the range of uncertainties as defined by the replicate analyses, a pooled mean age of $112 \pm 10 \mathrm{ka}$ was derived. The initial $\left({ }^{234} \mathrm{U} /{ }^{238} \mathrm{U}\right)$ activity ratios are within the uncertainty of the seawater value (Henderson 2002), however, this mainly stems for the large uncertainty on the derived ratios.

Sample E10 (Fowlers Bay) shows a potentially much simpler uranium behaviour, with more consistent uranium concentrations for 7 out of the 11 spots analysed (Figure 6b). The spots closest to the margins of the shell, show reduced uranium concentrations possibly indicating leaching. For the spots with consistent uranium concentrations, closed-system ${ }^{230} \mathrm{Th}$ ages range from $107 \pm 2 \mathrm{ka}$ to $126 \pm 2 \mathrm{ka}$ with a pooled mean age of $113 \pm 8 \mathrm{ka}$. Uranium concentrations decrease toward the 
shell margins indicating open-system behaviour. The pooled mean ages are in accord with the inferred age for the fossil molluscs based on aminostratigraphy and the morphostratigraphical context of the sedimentary successions.

\section{Discussion}

\section{The last interglacial (MIS 5e) sea level highstand on Eyre Peninsula}

The richly fossiliferous shelly successions of the Glanville Formation on western Eyre Peninsula, in terms of their general morphostratigraphy, developed in the latter stages of the Last Interglacial Maximum (MIS 5e) under conditions of a sea level highstand higher than attained in the present, Holocene interglacial. The shelly successions represent prograded shoreline sequences that fringe older Pleistocene successions or pre-Quaternary bedrock.

At Ceduna, radiocarbon dated regressive Holocene coastal facies do not reveal evidence for a sea level higher than present over the past 6000 radiocarbon years (Belperio, Harvey \& Bourman 2002). In contrast, evidence from the last interglacial successions host to in situ (biocenose) marine molluscan fossil assemblages point to a relative sea level of up to $2.1 \pm 0.5 \mathrm{~m}$ at Fowlers Bay, at least $2.55 \mathrm{~m}$ APSL and possibly as much as $4 \pm 0.5 \mathrm{~m}$ APSL at Tourville Bay, $3.4 \pm 0.5 \mathrm{~m}$ at Smoky Bay, and $3.5 \pm 0.5 \mathrm{~m}$ at Lake Newland. The transported (thanatocenose) molluscan fossil assemblages at Cape Thevenard and Denial Bay suggest that sea level during MIS 5e exceeded $3 \mathrm{~m}$ APSL, but these latter sea level indicators are of lower reliability. Older Pleistocene shelly limestones are not found inland or at higher elevations in the regional landscape, indicating that the last interglacial successions represent the highest level of marine inundation during the later Pleistocene preserved along this coastline.

The general uniformity in elevation of the upper bounding surfaces of the Glanville Formation (now protected by a strongly indurated calcrete), at each field site on western Eyre Peninsula, relative to present sea level, preclude the successions from representing transgressive facies associations during a rising stage of sea level in the early phase of the last interglacial maximum. In a similar manner, there is no field evidence for a bipartite sea level highstand or fluctuations in relative sea level during the interglacial as identified in earlier studies on Atauro Island (Chappell \& Veeh 1978), the Huon Peninsula (Aharon \& Chappell 1986), or more recently in the Bahamas (Thompson, Curran, Wilson \& White 2011) and western Australia (O'Leary et al. 2013). At each field site, and at other locations not sampled in this investigation, the landward limit of the Glanville Formation is defined by a distinct lensing out of the formation and there are no geomorphological features suggestive of a higher sea level during MIS 5e (e.g. absence of higher level shelly units than documented in this work, or shoreline notches in aeolianite of the 
Bridgewater Formation). On the landward margin of the Glanville Formation, the sediments abut consolidated older Pleistocene dune units of the Bridgewater Formation or in places pre-Quaternary bedrock. At several locations (e.g. Fowlers Bay, Lake Newland, Venus Bay), the Glanville Formation was deposited within well-defined landscape depressions landward of aeolianite, which has constrained the spatial extent of the formation.

The Katelysia sp., dominated shell assemblages represent shoaling upward successions that developed during a sea level highstand and the progressive decline in sediment accommodation

space. Accordingly, it is inferred that the near surface deposits are genetically related to the highest point of sea level in a single highstand of the last interglacial maximum (MIS 5e). Similar sedimentary successions of Holocene age occur seaward of the Glanville Formation along the coastline of western Eyre Peninsula (e.g. Baird Bay, Decres Bay, Streaky Bay and Tourville Bay). Near Robe in southern South Australia equivalent shelly successions (coquinas) up to $3 \mathrm{~m}$ thick, have formed from about 7000 years ago at the culmination of the marine transgression following the Last Glacial Maximum (Cann, Murray-Wallace, Belperio \& Brenchley 1999), and represent a Holocene analogue of the last interglacial successions of western Eyre Peninsula.

It must also be stressed that the shelly successions mapped as Glanville Formation do not relate to younger, interstadial events of the last interglacial sensu lato (i.e. MIS 5c at c. $105 \mathrm{ka}$ or MIS $5 \mathrm{a}$ at c. $82 \mathrm{ka}$ ). In global context, these events equate with larger ice volumes of the continental ice sheets and lower sea levels of 21-15 m BPSL and 25-13 m BPSL respectively, representing the onset of the last glacial cycle (Murray-Wallace \& Woodroffe 2014).

A limitation in the data set presented in this work relates to the general absence of corals suitable for U-series analysis which would otherwise permit a framework for direct comparison with the well-dated and higher-resolution coral reef relative sea level records of Western Australia. Thus, although relative sea-level changes during MIS 5e based on the available outcrop information cannot be defined at present, the maximum elevation of MIS 5e sea level on Eyre Peninsula can be quantified.

\section{The Eyre Peninsula last interglacial (MIS 5e) sea level highstand in an Australian context}

Although in a global context Australia shows a high degree of tectonic stability, spatial variation is evident at the regional landscape scale $(>10-100 \mathrm{~km})$ in the elevation of coastal sedimentary successions of last interglacial age (MIS 5e) (Murray-Wallace \& Belperio 1991; Murray-Wallace 2002). Notwithstanding the influence of glacio-hydro-isostatic adjustment processes, some of the variation in elevation of shoreline successions is unambiguously related to their geotectonic setting, and in particular, their pre-Quaternary physical landscape and tectonic setting. In the Adelaide 
Plains Basin for example, where the last interglacial Glanville Formation was first defined stratigraphically (Firman 1966), the upper-bounding surface of the succession occurs $0.5 \mathrm{~m}$ above tidal low water datum at Dry Creek (Belperio, Hails \& Gostin 1983), and up to $6 \mathrm{~m} \mathrm{BPSL}$ at Glanville (Howchin 1888; Ludbrook 1976), reflecting the longer-term subsidence history of the Adelaide Plains Basin (Belperio 1993). In contrast, at Normanville on southern Fleurieu Peninsula, the succession occurs up to $12 \mathrm{~m}$ APSL and $6 \mathrm{~m}$ APSL at Victor Harbor reflecting the longer-term, differential uplift history of the southern Mount Lofty Ranges (Bourman, Belperio, Murray-Wallace \& Cann 1999). In the Murray Mouth - Coorong Lagoon area the upper-bounding surface of the formation occurs up to $2 \mathrm{~m}$ APSL and over a horizontal distance of some $300 \mathrm{~km}$ rises to $18 \mathrm{~m}$ APSL near Mount Gambier (Murray-Wallace et al. 1996; Murray-Wallace 2002). Although there is a paucity of preserved last interglacial coastal successions in New South Wales, resulting from fluvial erosion during the last glacial cycle, particularly within constrained bedrock depressions, an estuarine succession at Largs in the tectonically stable northern Hunter Valley remains important for documenting sea level. The estuarine shell bed, containing a diverse molluscan fauna dominated by $A$. trapezia, occurs between 2-3 m APSL indicating a sea level of $4 \pm 1 \mathrm{~m}$ APSL at the time of deposition (Thom \& Murray-Wallace 1988; Murray-Wallace, Leary \& Kimber 1996). In Australia the highest elevations of last interglacial (MIS 5e) coastal successions have been documented from Tasmania ranging from $10 \mathrm{~m}$ up to $32 \mathrm{~m}$ APSL reflecting neotectonic processes of an unresolved nature as the eastern portion of the Australian continent moved north across a mantle hot spot (Bowden \& Colhoun 1984; Murray-Wallace \& Goede 1995).

The coral reef successions of Western Australia have been examined extensively for their last interglacial records of relative sea-level changes as they are readily amenable to U-series analysis and are also situated in the far-field of Pleistocene ice sheets (Eisenhauer et al. 1993; McCulloch \& Esat 2000; Hearty et al. 2007; O'Leary et al. 2013). At the regional landscape scale, with the exception of the Cape Range and Cape Cuvier regions (Whitney \& Hengesh 2015), the majority of the coastline shows a high degree of tectonic stability. Based on a study of drill core from Turtle Bay, Houtman Abrolhos Islands, Eisenhauer et al. (1996) reported that following the penultimate glaciation (MIS 6), sea level had risen to approximately $4 \mathrm{~m}$ BPSL by $134 \mathrm{ka}$ and attained a highstand of at least $3.3 \mathrm{~m}$ APSL by $124 \mathrm{ka}$. At Leander Point, $400 \mathrm{~km}$ north of Perth, Faviidae corals reach a maximum elevation of $2.2 \mathrm{~m}$ above modern intertidal platform and have been dated at $123.4 \pm 0.9 \mathrm{ka}$ and up to $2.43 \mathrm{~m}$ at Rottnest Island with a U-series age of $126 \pm 0.8 \mathrm{ka}$ implying a higher sea level of up to $3 \mathrm{~m}$ APSL. Zhu et al. (1993) also reported U-series ages on corals from coral platforms of the Houtman Abrolhos Islands that are typically 2-3 m APSL. They concluded that a sea level of approximately $2 \mathrm{~m}$ APSL was attained by $133 \mathrm{ka}$, that the highstand 
lasted until about $116 \mathrm{ka}$ and for much of that time sea level was at $4 \mathrm{~m}$ APSL, apart from the possibility of a brief period of a higher sea level of up to $6 \mathrm{~m}$ APSL, based on the elevation of the top of an undated framestone facies at $4 \mathrm{~m}$ APSL.

In assessing the reliability of $U$-series coral ages based on $\delta^{234} U$ values from Western Australia, McCulloch \& Esat (2000) concluded that the U-series results indicate that sea level attained a maximum height of 2-4 m APSL by $128 \pm 1 \mathrm{ka}$ and remained broadly at $4 \mathrm{~m}$ APSL until $120 \pm 1 \mathrm{ka}$, followed by a sea level fall after that time.

O'Leary et al. (2013) reported U-series ages on last interglacial corals from numerous coastal sites in Western Australia. They noted a prolonged highstand of 3-4 m APSL from 127 to $119 \mathrm{ka}$ consistent with the afore-mentioned investigations. They then suggested, based on results from the Quobba Ridge region (Cape Cuvier Anticline; Whitney \& Hengesh 2015) that sea level subsequently rose to $9 \mathrm{~m}$ APSL by $118.1 \pm 1.4 \mathrm{ka}$ based on a single U-series age and attribute the relative rise in sea level to a late phase of ice sheet collapse before the end of the last interglacial maximum. Critical to their interpretation is the reliability of the $118 \mathrm{ka} \mathrm{U}$-series age for coral from the upper level terrace.

In comparing the palaeo-sea level observations from western Eyre Peninsula with Western Australia, some commentary is warranted on the tectonic stability of the Cape Range and Cape Cuvier regions of north Western Australia. Both regions have been subject to controversy over their inferred relative sea level records for the last interglacial maximum (Hearty et al. 2007; Whitney \& Hengesh 2015). While inferred last interglacial sea levels up to $4 \mathrm{~m}$ APSL have been determined from a significant portion of the Western Australian coastline from Rottnest Island to Shark Bay, palaeoshoreline data from the Cape Range - Cape Cuvier region indicate relative sea levels up to $9 \mathrm{~m}$ APSL. The tectonic setting of the Cape Range - Cape Cuvier region has been thoroughly reviewed and shown to have undergone neotectonic deformation during the late Pleistocene thus explaining the higher elevation of last interglacial shoreline features in this setting (Whitney \& Hengesh 2015).

The last interglacial coastal successions from the $300 \mathrm{~km}$ sector of western Eyre Peninsula indicate that sea level reached a height between 2.1 $\pm 0.5 \mathrm{~m}$ APSL (Fowlers Bay) to possibly as much as $4 \pm 0.5 \mathrm{~m}$ APSL (Tourville Bay) and is consistent with the inferred high degree of tectonic stability of the region. Variation in the inferred palaeosea level elevations may relate to the different successions chronicling discrete intervals of time during the highstand that are not resolvable by the geochronological methods used in this investigation and the possibility of minor erosion of some of the successions during the last glacial cycle. In terms of general order of magnitude, the inferred palaeo-sea levels from western Eyre Peninsula are in accord with those 
inferred from the coralline successions from much of the Western Australian coastline and point to a last interglacial sea level maximum below $5 \mathrm{~m}$ APSL for the entire interglacial sea level highstand.

\section{The Eyre Peninsula MIS 5e sea level highstand record in a global context}

The evaluation of inferred relative sea levels from western Eyre Peninsula in a global context requires a comparison with relative sea level records from other far-field sites that are also considered tectonically stable, as well as other frameworks for inferring palaeo-sea level for MIS $5 \mathrm{e}$.

The early global designation of sea-level zones by Clark et al., (1978) based on proximity to Pleistocene ice sheets and consequent relative sea level records suggested that Australia, southern Africa, Madagascar and southern South America represent far-field regions that may have experienced similar relative sea level histories provided they are tectonically stable.

Although the coastline of eastern Patagonia falls within a far-field zone it shows evidence for ongoing tectonism with marine terraces of last interglacial age (MIS 5e) commonly between 10 to $20 \mathrm{~m}$ APSL (Pedoja et al., 2011) precluding a direct estimate of glacio-eustatic (ice-equivalent) sea level along this coastal margin.

The relative sea level record of the southern Cape coastline of South Africa reveals a maximum highstand of between 6 to $8.5 \mathrm{~m}$ APSL for the last interglacial maximum (Carr et al. 2010). Cooper \& Flores (1991) described raised shallow water near-shore, beach and dune deposits of presumed last interglacial (MIS 5e) age deposited on a bevelled surface 4.5 to $5 \mathrm{~m}$ APSL at Isipingo Beach approximately $20 \mathrm{~km}$ south-west of Durban. In a general sense this accords with the 'shoreline of emergence' at approximately $6 \mathrm{~m}$ APSL noted by Krige (1927) along $1500 \mathrm{~km}$ of coastline from Durban to Port Nolloth. In Madagascar, the highest recorded level of MIS 5e coral reef terraces occur up to 5-6 m APSL (Montaggioni, 2010).

Based on a review of coral reef successions from sites predominantly located in the equatorial realm, the screening of their U-series ages, and the modelling of glacio-isostatic adjustment processes, Dutton and Lambeck (2012) concluded that glacio-eustatic (ice-equivalent) sea level peaked at between 5.5 to $9 \mathrm{~m}$ APSL during the last interglacial maximum (MIS 5e). Critically, these observations are based on the only two far-field sites regarded as tectonically stable, Western Australia and the Seychelles respectively.

Defining the elevation of glacio-eustatic (ice-equivalent) sea level for MIS 5e from tectonically active settings is complicated by the circular problem of determining the rate of tectonic uplift. As noted in the introduction, many early studies assumed a value of $6 \mathrm{~m}$ APSL which was 
then used to quantify a rate of coastal emergence and assign ages to older and younger reef terraces. Subsequent workers have started to invoke a lower value for MIS 5e sea level in uplift rate calculations. Based on detailed mapping and geochronological investigations of the coral reef successions of Barbados, Schellmann and Radtke (2004a,b) adopted a value of $2 \pm 2 \mathrm{~m}$ APSL for MIS 5e sea level in their uplift rate calculations for southern Barbados. In a similar manner, Pedoja et al, (2011) invoked a value of $3 \pm 1 \mathrm{~m}$ APSL in quantifying rates of tectonic uplift in Patagonia.

The inferred last interglacial sea levels from western Eyre Peninsula of between $2.1 \pm 0.5 \mathrm{~m}$ APSL (Fowlers Bay) to possibly as much as $4 \pm 0.5 \mathrm{~m}$ APSL (Tourville Bay) fall within the lower range of estimates for MIS 5e in a global context, where the maximum inferred values attain up to 9 m APSL (Hearty et al. 2007; Kopp et al. 2009; Dutton \& Lambeck, 2012; Long et al. 2015). Western Eyre Peninsula is arguably the most remote far-field setting in the world and therefore potentially more sensitive to registering relative sea-level changes that more closely approximate glacio-eustatic (ice-equivalent) sea level.

The results of this investigation suggest that ice volumes were larger during MIS 5e (i.e. Greenland and Antarctic contributions as well as contributions from valley glaciers). Studies examining Holocene relative sea-level changes in southern Australia have shown that the southern portion of Eyre Peninsula shows minimal effect of hydro-isostasy following the attainment of the Holocene sea level highstand some 7000 years ago (Belperio, Harvey \& Bourman 2002). In contrast, systematic differences in the maximum height attained by the highstand are evident in a northward trend up both the South Australian gulfs. By implication, these observations suggest that on the open ocean coastline of Eyre Peninsula, a hydro-isostatic contribution is likely to be minimal in the last interglacial relative sea level record suggesting that the inferred relative sea levels from the Glanville Formation shelly successions is representative of the maximum sea level attained during the last interglacial maximum along this far-field coastal margin.

\section{Conclusions}

(1) Richly fossiliferous low-energy, shoaling upward, shallow subtidal to peritidal bioclastic carbonate successions of the Glanville Formation along a $300 \mathrm{~km}$ coastal sector of western Eyre Peninsula formed within back-barrier estuarine-lagoonal environments during the Last Interglacial Maximum (MIS 5e). Their time-equivalence with the Glanville Formation informal reference section at Dry Creek in the Adelaide Plains Basin has been confirmed by aminostratigraphy. U-series analyses on the robust bivalve mollusc Anadara trapezia cautiously point to the potential utility of dating this species and also suggest a correlation 
with the Last Interglacial Maximum (MIS 5e) with pooled mean ages of $113 \pm 8 \mathrm{ka}$ (Fowlers Bay) and $112 \pm 10 \mathrm{ka}$ (Lake Newland).

(2) The shelly successions were deposited in well-defined intertidal to shallow subtidal environments and indicate a higher sea level of between $2.1 \pm 0.5$ to $4 \pm 0.5 \mathrm{~m}$ APSL during the Last Interglacial Maximum (MIS 5e) along this coastline. Differences in the inferred palaeo-sea levels at the different field sites may relate to sea level variability during the MIS 5e highstand but cannot yet be geochronologically resolved given the analytical uncertainties of the methods presently available.

(3) In a global context the Glanville Formation sediments from western Eyre Peninsula, a farfield and tectonically stable setting define a lower limit of inferred relative sea level for the Last Interglacial Maximum (MIS 5e) highstand and imply larger ice volumes during MIS $5 \mathrm{e}$.

\section{Acknowledgements}

This research was supported by an Australian Research Council Discovery Project Grant (DP0559159) and is a contribution to the GeoQuEST Research Centre, University of Wollongong. The line drawings were skilfully prepared by Peter Johnson. We thank Dan Muhs and an anonymous reviewer for their thoughtful and constructive reviews of this work. 


\section{References}

Aharon, P. \& Chappell, J. (1986). Oxygen isotopes, sea level changes and temperature history of a coral reef environment in New Guinea over the last $10^{5}$ years. Palaeogeography, Palaeoclimatology, Palaeoecology, 56, 337-379.

Australian Climate Averages, Bureau of Meteorology, Australian Government.

Banerjee, D., Hildebrand, A. N., Murray-Wallace, C. V., Bourman, R. P., Brooke, B. P. \& Blair, M. (2003). New quartz SAR-OSL ages from the stranded beach dune sequence in south-east South Australia. Quaternary Science Reviews, 22, 1019-1025.

Belperio, A. P. (1988). Fowlers Bay rotary drilling report and revision of the Quaternary geology around Fowlers Bay. Report Book No. 88/93, Department of Mines and Energy, South Australia 51 pp plus maps.

Belperio, A. P. (1993). Land subsidence and sea level rise in the Port Adelaide estuary: implications for monitoring the greenhouse effect. Australian Journal of Earth Sciences, 40, 359-368.

Belperio, A. P. (1995). Chapter 11. Quaternary. In: Drexel, J.F., Preiss, W.V. (Eds.), The geology of South Australia, Volume 2, The Phanerozoic, South Australia Geological Survey, Bulletin 54, pp. 218-280.

Belperio, A. P., Gostin, V. A., Cann, J. H. \& Murray-Wallace, C. V. (1988). Sediment-organism zonation and the evolution of Holocene tidal sequences in southern Australia. In: De Boer, P. L., Van Gelder, A. \& NIO, S. D. (Eds), Tide-influenced sedimentary environments and facies, D. Reidel, Dordrecht, pp. 475-497.

Belperio, A. P., Hails, J. R. \& Gostin, V. A. (1983). A review of Holocene sea levels in South Australia. In: Hopley, D. (Ed), Australian sea levels in the last 15000 years: A review. Department of Geography, James Cook University of North Queensland, Townsville, pp.37-47. Belperio, A. P., Harvey, N. \& Bourman, R. P. (2002). Spatial and temporal variability in the Holocene sea-level record of the South Australian coastline. Sedimentary Geology, 150, 153169.

Belperio, A. P., Murray-Wallace, C. V. \& Cann, J. H. (1995). The last interglacial shoreline in southern Australia: morphostratigraphic variations in a temperate carbonate setting. Quaternary International, 26, 7-19.

Belperio, A. P., Smith, B. W., Polach, H. A., Nittrouer, C. A., De Master, D. J., Prescott, J. R., Hails, J. R. \& Gostin, V. A. (1984). Chronological studies of Quaternary marine sediments of northern Spencer Gulf, South Australia. Marine Geology, 61, 265-296. 
Bernal, J. -P., Eggins, S. M. \& McCulloch, M. T. (2005). Accurate in situ ${ }^{238} \mathrm{U}^{-234} \mathrm{U}-{ }^{232} \mathrm{Th}-{ }^{230} \mathrm{Th}$ analysis of silicate glasses and iron oxides by laser-ablation MC-ICP-MS. Journal of Analytical Atomic Spectrometry, 20, 1240-1249.

Blakemore, A., Murray-Wallace, C. V. \& Lachlan, T. J. (2014). First recorded evidence of subaqueously-deposited late Pleistocene interstadial (MIS 5c) coastal strata above present sea level in Australia. Marine Geology, 335, 377-383.

Blakemore, A., Murray-Wallace, C. V., Westaway, K. E. \& Lachlan, T. J. (2015). Aminostratigraphy and sea level history of the Pleistocene Bridgewater Formation, Mount Gambier region, southern Australia. Australian Journal of Earth Sciences, 62, 151-169.

Bloom, A. L., Broecker, W. C., Chappell, J., Matthews, R. S., Mesolella, K. J. (1974). Quaternary sea level fluctuations on a tectonic coast: New $\mathrm{Th}^{230} / \mathrm{U}^{234}$ dates from New Guinea. Quaternary Research, 4, 185-205.

Bourman, R. P., Belperio, A. P., Murray-Wallace, C. V. \& Cann, J. H. (1999). A last interglacial embayment fill at Normanville, South Australia and its neotectonic implications. Royal Society of South Australia, Transactions, 123, 1-15.

Bourman, R. P., Murray-Wallace, C. V. \& Harvey, N. (2016). Coastal Landscapes of South Australia, University of Adelaide Press, Adelaide, 420 pp.

Boutakoff, N. (1963). The geology and geomorphology of the Portland area. Victoria Geological Survey, Memoir 22, pp. 172.

Bowden, A. R. \& Colhoun, E. A. (1984). Quaternary emergent shorelines in Tasmania. In, B. G. Thom (Ed), Coastal Geomorphology in Australia, Academic Press, Sydney, pp. 313-342.

Braun, J., Burbidge, D. R., Gesto, F. N., Sandiford, M., Gleadow, A. J. W., Kohn, B. P. \& Cummins, P. R. (2009). Constraints on the current rate of deformation and surface uplift of the Australian continent from a new seismic database and low-T thermochronological data. Australian Journal of Earth Sciences, 56, 99-110.

Broecker, W. C., Thurber, D. L., Goddard, J., Ku, T. L., Matthews, R. K. \& Mesolella, K. J. (1968). Milankovitch hypothesis supported by precise dating of coral reefs and deep sea sediments. Science, 159, 297-300.

Bureau of Meteorology (2015). Tide predictions for Australia, South Pacific and Antarctica; www.bom.gov.au/australia/tides.

Cann, J. H. (1978). An exposed reference section for the Glanville Formation. Quarterly Geological Notes, Geological Survey of South Australia, 65, 2-4. 
Cann, J. H. \& Clarke, J. D. A. (1993). The significance of Marginopora vertebralis (Foraminifera) in surficial sediments at Esperance, Western Australia, and in last interglacial sediments in northern Spencer Gulf, South Australia. Marine Geology, 111, 171-187.

Cann, J. H. \& Gostin, V. A. (1985). Coastal sedimentary facies and foraminiferal biofacies of the St Kilda Formation at Port Gawler, South Australia. Transactions of the Royal Society of South Australia, 109, 121-142.

Cann, J. H., Murray-Wallace, C. V., Belperio, A. P. \& Brenchley, A. J. (1999). Evolution of Holocene coastal environments near Robe, southeastern South Australia. Quaternary International, 56, 81-97.

Carr, A. S., Bateman, M. D., Roberts, D. L., Murray-Wallace, C. V., Jacobs, Z., \& Holmes, P. J. (2010). The last interglacial sea-level high stand on the southern Cape Coastline of South Africa. Quaternary Research, 73, 351-363.

Chappell, J. (1974). Geology of coral terraces, Huon Peninsula, New Guinea. Geological Society of America Bulletin, 85, 553-570.

Chappell, J. \& Veeh, H. H. (1978). Late Quaternary tectonic movements and sea-level changes at Timor and Atauro Island. Geological Society of America Bulletin, 89, 356-368.

Clark, D. \& Leonard, M. (2003). Principal stress orientations from multiple focal-plane solutions: new insight into the Australian intraplate stress field. In: Hillis, R.R. \& Müller, R.D. (Eds.), Evolution and dynamics of the Australian Plate, Geological Society of Australia Special Publication, 22, 91-105.

Clark, J. A., Farrell, W. E. \& Peltier, W. R. (1978). Global changes in postglacial sea level: a numerical calculation. Quaternary Research, 9, 265-287.

Clitheroe, G., Gudmunsson, O. \& Kennett, B. L. N. (2000). The crustal thickness of Australia. Journal of Geophysical Research, 105, 13,697-13,713.

Cooper, J. A. G. \& Flores, R. M. (1991). Shoreline deposits and diagenesis resulting from two Late Pleistocene highstands near +5 and +6 metres, Durban, South Africa. Marine Geology, 97, 325-343.

Creveling, J. R., Mitrovica, J. X., Hay, C. C., Austermann, J. \& Kopp, R. E. (2015). Revisiting tectonic corrections applied to Pleistocene sea-level highstands. Quaternary Science Reviews, 111, $72-80$.

Daniel, R. F. (2002). Carbonate sediments of a cool water embayment, Streaky Bay, South Australia, Unpublished PhD thesis, University of Adelaide.

Deshayes, G. P. (1840). Nouvelles espèces de mollusques, provenant des côtes de la Californie, du Mexique, du Kamtschatka et de la Nouvelle-Zélande. Revue Zoologique, par la Société 
Cuvierienne; Association Universelle pour l'Avancement de Zoologie, de l'Atomie Comparée et de la Paléontologie; Journal Mensuel. Publié sous la Direction de M.F.-E. GuérinMéneville. Année 1839, Vol. 2, 356-361, pl. 21.

Dutton, A. \& Lambeck, K. (2012). Ice volume and sea level during the last interglacial. Science, 337, 216-219.

Eggins, S., Grün, R, McCulloch, M., Pike, A., Chappell, J., Kinsley, L., Mortimer, G., Shelley, M, Murray-Wallace, C. V., Spötl, C., \& Taylor, C. S. L. (2005). In situ U-series dating by laserablation multi-collector ICPMS: new prospects for Quaternary geochronology. Quaternary Science Reviews, 24, 2523-2538.

Eisenhauer, A., Zhu, Z. R., Collins, L. B., Wyrwoll, K. H. \& Eichstätter, R. (1996). The last interglacial sea level change: new evidence from the Abrolhos islands, West Australia. Geologische Rundschau, 85, 606-614.

Firman, J. B. (1966). Stratigraphic units of Late Cainozoic age in the St Vincent Basin, South Australia. Quarterly Geological Notes, Geological Survey of South Australia, 17, 6-9.

Flint, R. B. (1987). Explanatory notes for the NUYTS 1:250 000 geological map Sheet SI/53-1, Geological Survey of South Australia, D. J. Woolman, Government Printer, South Australia, pp. 30.

Flint, R. B. (1992). Explanatory notes for the ELLISTON 1:250 000 geological map Sheet SI 53-6, Geological Survey of South Australia, Kitchener Press, Adelaide, pp. 40.

Hand, M., Reid, A. \& Jagodzinski, L. (2007). Tectonic framework and evolution of the Gawler Craton, Southern Australia. Economic Geology, 102, 1377-1395.

Harte, M. E. (1998). Superfamily Veneroidea. In: Beesley, P. L., Ross, G. J. B. \& Wells, A. (Eds). Mollusca: The Southern Synthesis. Fauna of Australia, Vol. 5, pp. 355-362, CSIRO Publishing, Melbourne, Part B.

Hearty, P. J., Hollin, J. T., Neumann, A. C., O’Leary, M. J. \& McCulloch, M. (2007). Global sealevel fluctuations during the Last Interglaciation (MIS 5e). Quaternary Science Reviews, 26, 2090-2112.

Henderson, G. M. (2002). Seawater $\left({ }^{234} \mathrm{U} /{ }^{238} \mathrm{U}\right)$ during the last 800 thousand years. Earth Planetary Science Letters, 199: 97-110.

Hoffmann, D. L., Prytulak, J., Richards, D. A., Elliot, T., Coath, C. D., Smart, P. L. \& Scholz, D. (2007). Procedures for accurate $\mathrm{U}$ and Th isotope measurements by high precision MCICPMS. International Journal of Mass Spectrometry, 264, 97-109. 
Howchin, W. (1888). Notes on a geological section at the new graving dock, Glanville, with special reference to a supposed old land surface now below sea level. Transactions of the Royal Society of South Australia, 10, 31-35.

Huntley, D. J., Hutton, J. T. \& Prescott, J. R. (1993). The stranded beach-dune sequence of southeast South Australia: a test of thermoluminescence dating. Quaternary Science Reviews, 12, 120.

Huntley, D. J., Hutton, J. T. \& Prescott, J. R. (1994). Further thermoluminescence dates from the dune sequence in the south-east of South Australia. Quaternary Science Reviews, 13, 201-207.

James, N. P. \& Bone, Y. (2011). Neritic carbonate sediments in a temperate realm. Springer, Dordrecht, pp. 252.

Kaufman, A., Broecker, W. S., Ku, T. -L. \& Thurber, D. L. (1971). The status of U-series methods of mollusk dating. Geochimica et Cosmochimica Acta, 35, 1155-1183.

Kaufman, D. S. \& Manley, W. F. (1998). A new procedure for determining enantiomeric (D/L) amino acid ratios in fossils using reverse phase liquid chromatography. Quaternary Science Reviews, 17, 987-1000.

Kharazizadeh, N., Schellart, W. P., Duarte, J. C. \& Hall, M. (2016). The variation of crustal stretching and different modes of rifting along the Australian southern continental margin. Australian Journal of Earth Sciences, 63, 159-174.

Kopp, R. E., Simons, F. J., Mitrovica, J. X., Maloof, A. C. \& Oppenheimer, M. (2009). Probabilistic assessment of sea level during the last interglacial stage. Nature, 462, 863-867.

Krige, A. V. (1927). An examination of Tertiary and Quaternary changes of sea-level in South Africa, with special stress on the evidence in favour of a recent world-wide sinking of ocean level. Annals of the University of Stellenbosch, Capetown, Vol. 5, Section A, No. 1, pp. 1-81 $\& 5$ plates.

Lachlan, T. J. (2011). Aminostratigraphy and luminescence dating of the Pleistocene Bridgewater Formation, Kangaroo Island, South Australia: An archive of long term climate and sea-level change. Unpublished PhD Thesis, University of Wollongong, 713 pp.

Lajoie, K. R., Wehmiller, J. F. \& Kennedy, G. L. (1980). Inter- and intrageneric trends in apparent racemization kinetics of amino acids in Quaternary mollusks. In, Hare, P. E., Hoering, T. C. \& King, K. (eds), Biogeochemistry of Amino Acids, pp. 305-340, John Wiley and Sons, New York.

Lambeck, K. \& Nakada, M. (1992). Constraints on the age and duration of the last interglacial period and on sea-level variations. Nature, 357, 125-128. 
Lambeck, K., Purcell, A. \& Dutton, A. (2012). The anatomy of interglacial sea levels: the relationship between sea levels and ice volumes during the Last Interglacial. Earth and Planetary Science Letters, 315-316, 4-11.

Lewis, S. E., Sloss, C. R., Murray-Wallace, C. V., Woodroffe, C. D. \& Smithers, S. G. (2013). Post-glacial sea-level changes around the Australian margin: a review. Quaternary Science Reviews, 74, 115-138.

Long, A. J., Barlow, N. L. M., Busschers, F. S., Cohen, K. M., Gehrels, W. R. \& Wake, L. M. (2015). Near-field sea-level variability in northwest Europe and ice sheet stability during the last interglacial. Quaternary Science Reviews, 126, 26-40.

Ludbrook, N. H. (1976). The Glanville Formation at Port Adelaide. Quarterly Geological Notes, Geological Survey of South Australia, 57, 4-7.

Ludbrook, N. H. (1984). Quaternary molluscs of South Australia. South Australia, Department of Mines and Energy, Handbook No. 9, pp. 327.

Ludwig, K. R. (2003). User's Manual for Isoplot 3.00. Berkeley Geochronology Center, Berkeley, CA, USA.

Macpherson, J. H. \& Gabriel, C. J. (1962). Marine molluscs of Victoria. Melbourne University Press, Melbourne, 475 pp.

Marine and Harbours (1994). Tide Tables - South Australian Ports. Department of Marine and Harbors, South Australia.

Masson-Delmotte, V., Stenni, B., Pol, K., Braconnot, P., Cattani, O., Falourd, S., Kageyama, M., Jouzel, J., Landais, A., Minster, B., Barnola, J. M., Chappellaz, J., Krinner, G., Johnson, S., Röthlisberger, R., Hansen, J., Mikolajewicz, U. \& Otto-Bliesner, B. (2010). EPICA Dome C record of glacial and interglacial intensities. Quaternary Science Reviews, 29, 113-128.

McCulloch, M. T. \& Esat, T. (2000). The coral record of last interglacial sea levels and sea surface temperatures. Chemical Geology, 169, 107-129.

McGowran, B., Li, Q., Cann, J., Padley, D., McKirdy, D. M. \& Shafik, S. (1997). Biogeographic impact of the Leeuwin Current in southern Australia since the late middle Eocene. Palaeogeography, Palaeoclimatology, Palaeoecology, 136, 19-40.

Milne, G. A. \& Mitrovica, J. X. (2008). Searching for eustasy in deglacial sea-level histories. Quaternary Science Reviews, 27, 2292-2302.

Mitrovica, J. X. \& Peltier, W. R. (1991). On postglacial geoid subsidence over the equatorial oceans. Journal of Geophysical Research, 96, 20053-20071. 
Montaggioni, L. F. (2010). Western Indian Ocean. In, Hopely, D. (Ed), Encyclopedia of Modern Coral Reefs: Structure, Form and Process. Springer Science \& Business Media, pp. 11841186.

Muhs, D. (2002). Evidence for the timing and duration of the last interglacial period from highprecision uranium-series ages of corals on tectonically stable coastlines. Quaternary Research, 58, 36-40.

Muhs, D., Simmons, K. R., Schumann, R. R., Groves, L. T., Mitrovica, J. X. \& Laurel, D. (2012). Sea-level history during the last interglacial complex on San Nicolas Island, California: implications for glacial isostatic adjustment processes, paleozoogeography and tectonics. Quaternary Science Reviews, 37, 1-25.

Muhs, D., Simmons, K. R. \& Steinke, B. (2002). Timing and warmth of the last interglacial period: new U-series evidence from Hawaii and Bermuda and a new fossil compilation for North America. Quaternary Science Reviews, 21, 1355-1383.

Murray-Wallace, C. V. (2000). Quaternary coastal aminostratigraphy: Australian data in a global context. In: Goodfriend, G. A., Collins, M. J., Fogel, M. L., Macko, S. A. \& Wehmiller, J. F. (Eds), Perspectives in amino acid and protein geochemistry. Oxford University Press, New York, pp.279-300.

Murray-Wallace, C. V. (2002). Pleistocene coastal stratigraphy, sea-level highstands and neotectonism of the southern Australian passive continental margin - a review. Journal of Quaternary Science, 17, 469-489.

Murray-Wallace, C. V. \& Belperio, A. P. (1991). The last interglacial shoreline in Australia - A review. Quaternary Science Reviews, 10, 441-461.

Murray-Wallace, C. V., Belperio, A. P., Bourman, R. P., Cann, J. H. \& Price, D. M. (1999). Facies architecture of a last interglacial barrier: a model for Quaternary barrier development from the Coorong to Mount Gambier Coastal Plain, southeastern Australia. Marine Geology, 158, 177195.

Murray-Wallace, C. V., Belperio, A. P., Cann, J. H., Huntley, D. J. \& Prescott, J. R. (1996). Late Quaternary uplift history, Mount Gambier region, South Australia. Zeitschrift für Geomorphologie, Suppl.-Bd. 106, 41-56.

Murray-Wallace, C. V., Beu, A., Kendrick, G. W., Brown, L. J., Belperio, A. P. \& Sherwood, J. E. (2000). Palaeoclimatic implications of the occurrence of the arcoid bivalve Anadara trapezia (Deshayes) in the Quaternary of Australasia. Quaternary Science Reviews, 19, 559-590.

Murray-Wallace, C. V., Bourman, R. P., Prescott, J. R., Williams, F., Price, D. M. \& Belperio, A. P. (2010). Aminostratigraphy and thermoluminescence dating of coastal aeolianites and the later 
Quaternary history of a failed delta: The River Murray Mouth region, South Australia. Quaternary Geochronology, 5, 28-49.

Murray-Wallace, C. V. \& Goede, A. (1995). Aminostratigraphy and electron spin resonance dating of Quaternary coastal neotectonism in Tasmania and the Bass Strait Islands. Australian Journal of Earth Sciences, 42, 51-67.

Murray-Wallace, C. V., Leary, S. P. \& Kimber, R. W. L. (1996). Amino acid racemisation dating of a last interglacial estuarine deposit at Largs, New South Wales. Proceedings of the Linnean Society of New South Wales, 116, 213-222.

Murray-Wallace, C. V. \& Woodroffe, C. D. (2014). Quaternary Sea-Level Changes: A Global Perspective, Cambridge University Press, Cambridge, 484 pp.

Nakada, M. \& Lambeck, K. (1989). Late Pleistocene and Holocene sea-level change in the Australian region and mantle rheology. Geophysical Journal, 96, 497-517.

Neumann, A. C. \& Moore, W. S. (1975). Sea level events and Pleistocene coral ages in the Northern Bahamas. Quaternary Research, 5, 215-224.

Nielsen, B. J. (1964). Studies of the genus Katelysia Römer, 1857 (Mollusca, Lamellibranchiata). Memoirs of the National Museum of Melbourne, 26, 219-257.

O’Leary, M. J., Hearty, P. J., Thompson, W. G., Raymo, M. E., Mitrovica, J. X. \& Webster, J. M. (2013). Ice sheet collapse following a prolonged period of stable sea level during the last interglacial. Nature Geoscience, 6, 796-800.

Parker, A. J. (1993). Chapter 2, Geological Framework, In: Drexel, J. F., Preiss, W. V., Parker, A. J. (Eds.), The geology of South Australia, Volume 1 The Precambrian, South Australia, Geological Survey Bulletin 54, pp. 9-31.

Parker, A. J., Fanning, C. M. \& Flint, R. B. (1985). Geology. In: Twidale, C. R., Tyler, M. J. \& Davies, M. (Eds). Natural History of Eyre Peninsula, Royal Society of South Australia, Occasional Publications, 4, pp. 21-45.

Pike, A. \& Hedges, R. (2002). U-series dating of bone using the diffusion-adsorption model. Geochimica et Cosmochimica Acta, 66, 4273-4286.

Rankin, L. R. \& Flint, R. B. (1991). Explanatory notes for the STREAKY BAY 1:250 000 geological map sheet, SI 53-2, Geological Survey of South Australia, Peacock Publications, Adelaide, pp. 40.

Roberts, D. (1984). The genus Katelysia (Bivalvia: Veneridae) in southern Australia. Journal of the Malacological Society of Australia, 6, 191-204.

Schellmann, G. \& Radtke, U. (2004a). A revised morpho- and chronostratigraphy of the Late and Middle Pleistocene coral reef terraces on Southern Barbados (West Indies). Earth-Science 
Reviews, 64, 157-187.

Schellmann, G. \& Radtke, U. (2004b). The Marine Quaternary of Barbados. Geographisches Institut der Universität zu Köln, Heft 81, 137 pp.

Schwebel, D. A. (1978). Quaternary stratigraphy of the southeast of South Australia. Unpublished $\mathrm{PhD}$ thesis, The Flinders University of South Australia.

Schwebel, D. A. (1984). Quaternary stratigraphy and sea-level variation in the southeast of South Australia. In: Thom, B.G. (Ed). Coastal geomorphology in Australia, Academic Press, Sydney, 291-311.

Shackleton, N. J. (1969). The last interglacial in the marine and terrestrial records. Proceedings of the Royal Society of London, Series B, 174, 135-154.

Shackleton, N. J., Chapman, M., Sánchez-Goñi, M. F., Pailler, D. \& Lancelot, Y. (2002). The Classic Marine Isotope Substage 5e. Quaternary Research, 58, 14-16.

Short, A. D. (2004). Beaches of the South Australian Coast and Kangaroo Island - A guide to their nature, characteristics, surf and safety. Sydney University Press, Sydney, pp. 346.

Short, A. D. \& Hesp, P. A. (1982). Wave, beach and dune interactions in southeastern South Australia. Marine Geology, 48, 259-284.

Short, A. D. \& Woodroffe, C. D. (2009). The Coast of Australia, Cambridge University Press, Cambridge, 288 pp.

Sprigg, R. C. (1952). The geology of the south-east province, South Australia, with special reference to Quaternary coast-line migrations and modern beach developments. Geological Survey of South Australia, Bulletin 29, 120 pp.

Stirling, C. H., Esat, T. M., McCulloch, M. T. \& Lambeck, K. (1995). High-precision U-series dating of corals from Western Australia and implications for the timing and duration of the Last Interglacial. Earth and Planetary Science Letters, 135, 115-130.

Szabo, B. \& Rosholt, J. (1969). Uranium-series dating of Pleistocene molluscan shells from southern California-An open system model. Journal of Geophysical Research, 74, 32533260.

Tate, R. (1879). The Anniversary address of the President. Transactions and Proceedings and Report of the Philosophical Society of South Australia, Adelaide for 1878-1879. pp. XXXIXIXXV.

Thom, B. G. \& Murray-Wallace, C. V. (1988). Last interglacial (Stage 5e) estuarine sediments at Largs, New South Wales. Australian Journal of Earth Sciences, 35, 571-574.

Thompson, W. G., Curran, H. A., Wilson, M. A. \& White, B. (2011). Sea-level oscillations during the last interglacial highstand recorded by Bahamas corals. Nature Geoscience, 4, 684-687. 
Twidale, C. R. \& Campbell, E. M. (1985). The form of the land surface. In: Twidale, C. R., Tyler, M. J. \& Davies, M. (Eds), Natural History of Eyre Peninsula, Royal Society of South Australia, Occasional Publications, 4, pp. 57-76.

Veeh, H. H. (19660. $\mathrm{Th}^{230} / \mathrm{U}^{238}$ and $\mathrm{U}^{234} / \mathrm{U}^{238}$ ages of Pleistocene high sea level stand. Journal of Geophysical Research, 71, 3379-3386.

Wehmiller, J. F., Simmons, K. R., Cheng, H. Edwards, R. L., Martin-McNaughton, J., York, L. L., Krantz, D. E., Shen, C. -C. (2004). Uranium-series coral ages from the US Atlantic Coastal Plain - the '80 ka problem' revisited. Quaternary International, 120, 3-14.

Whitney, B. B. \& Hengesh, J. V. (2015). Geomorphological evidence for late Quaternary tectonic deformation of the Cape Region, coastal west central Australia. Geomorphology, 241, 160174.

Wilson, C. C. (1991). Geology of the Quaternary Bridgewater Formation of southwest and central South Australia. Unpublished PhD Thesis, The Flinders University of South Australia.

Woodroffe, C. D. \& Murray-Wallace, C. V. (2012). Sea-level rise and coastal change: the past as a guide to the future. Quaternary Science Reviews, 54, 4-11.

Woods, J. E. T. (1862). Geological observations in South Australia: principally in the district south-east of Adelaide. Longman, Green, Longman, Roberts \& Green, London, 404 pp.

Wyrwoll, K. -H., Greenstein, B. J., Kendrick, G. W. \& Chen, G. S. (2009). The palaeoceanography of the Leeuwin Current: implications for a future world. Journal of the Royal Society of Western Australia, 92, 37-51.

Zhu, Z. R., Wyrwoll, K. -H., Collins, L. B., Chen, J. H., Wasserburg, G. J. \& Eisenhauer, A. (1993). High-precision U-series dating of last interglacial events by mass spectrometry: Houtman Abrolhos Islands, Western Australia. Earth and Planetary Science Letters, 118, 281-293.

Zuber, M. T., Bechtel, T. D. \& Forsyth, D. W. (1989). Effective elastic thickness of the lithosphere and mechanisms of isostatic compensation in Australia. Journal of Geophysical Research, 94, 9353-9367. 


\section{Figures}

Figure.1 Location map of the study area and principal coastal embayments of western Eyre Peninsula. The hachured line delineates the landward margin of the Chandada Plains, a gently undulating, low relief landscape of calcreted Pleistocene aeolianite of the Bridgewater Formation.

Figure. 2a Map of Fowlers Bay, showing the extent of the last interglacial Glanville Formation, and $2 b$, illustrating a stratigraphical cross-section based on rotary drill hole data of Belperio (1988).

Figure. 3 The regional landscape of Fowlers Bay, illustrating the low surface relief of the last interglacial (MIS 5e) estuarine-lagoonal facies of the Glanville Formation. Holocene coastal dunes are visible in the horizon.

Figure 4. A detached block of back-barrier, estuarine-lagoonal facies of the Glanville Formation, Fowlers Bay (sample site EP\#2). The assemblage is dominated by articulated Katelysia sp.

Figure. 5 Extent of glutamic acid racemization in the fossil marine molluscs Anadara trapezia and Katelysia sp., from the late Pleistocene Glanville Formation, western Eyre Peninsula (plotted for sequential sites from west to east), compared with the type section of the formation at Dry Creek, Adelaide Plains, South Australia. Results for Katelysia sp., from the Holocene St. Kilda Formation are shown for comparison.

Figure 6. (a) Uranium concentrations (ppm) represented by open diamonds and derived U/Th numeric ages (solid squares) in a cross-section of the fossil bivalve mollusc Anadara trapezia from Lake Newland (sample E103). Uranium mobility is clearly evident, with a strong gradient in concentrations across the shell; (b) Uranium concentrations (ppm) and derived $\mathrm{U} / \mathrm{Th}$ numeric ages in a cross-section of the fossil bivalve mollusc Anadara trapezia from Fowlers Bay (sample E10). The sample shows simpler uranium behaviour, with very consistent uranium concentrations for 7 out the 11 spots analysed. Age uncertainties represent one standard deviation. 


\section{Tables}

Table 1 Fossil marine mollusc species and palaeoenvironments of the late Pleistocene Glanville Formation, Eyre Peninsula, South Australia.

Table 2: Extent of amino acid racemization (total hydrolysable amino acids - THAA) in fossil marine molluscs, from the late Pleistocene Glanville Formation, western Eyre Peninsula, South Australia.

Table 3 Extent of amino acid racemization (total hydrolysable amino acids - THAA) in fossil molluscs from the Holocene St Kilda Formation and modern molluscs, western Eyre Peninsula, South Australia.

Table 4 Aminostratigraphical correlation of the last interglacial Glanville Formation based on the extent of amino acid racemization in the fossil mollusc Anadara trapezia.

Table 5 Results of Uranium-series analyses on the fossil mollusc Anadara trapezia from Fowlers Bay and Lake Newland, western Eyre Peninsula, South Australia. 
Figure 1

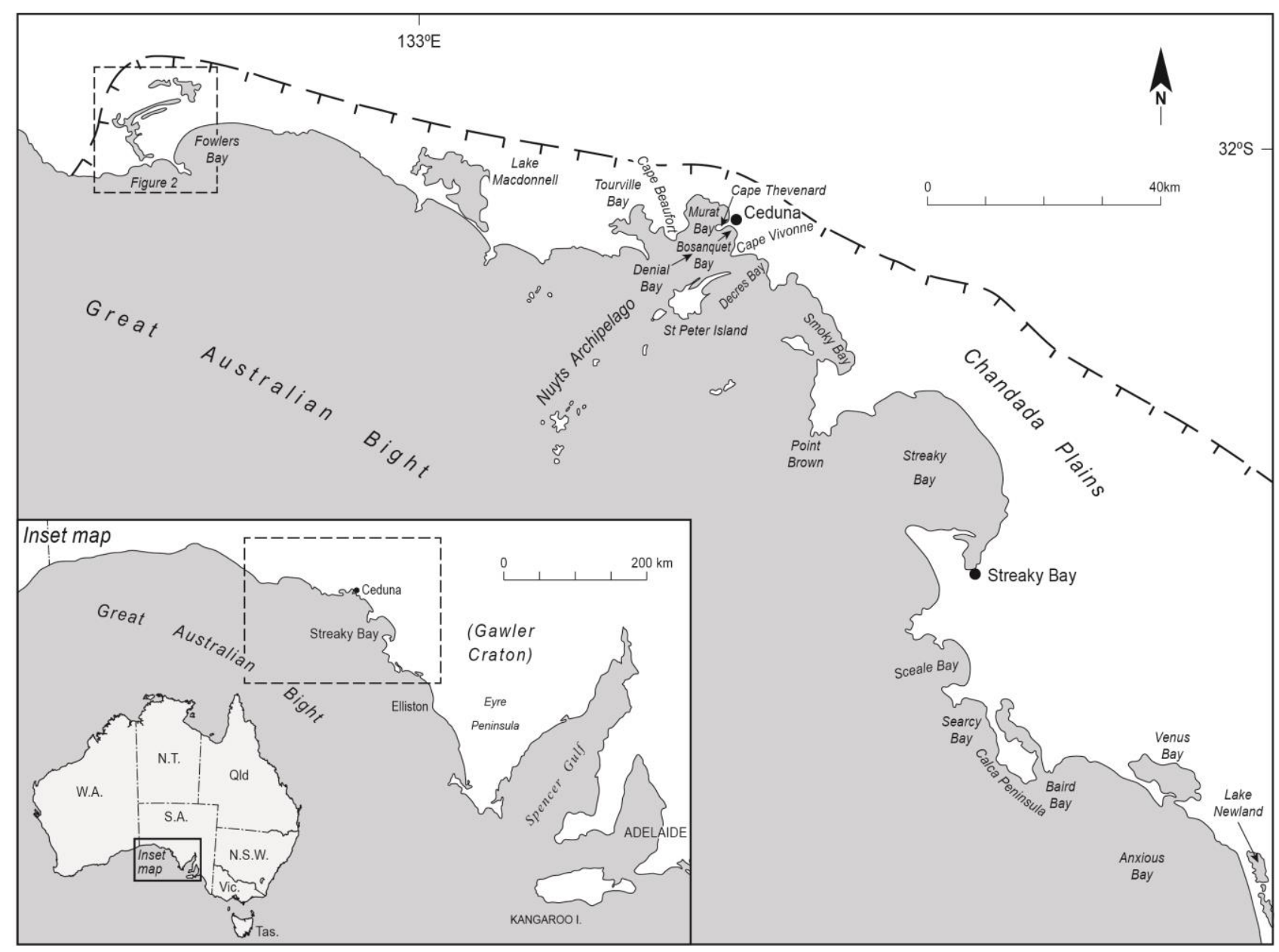


Figure 2

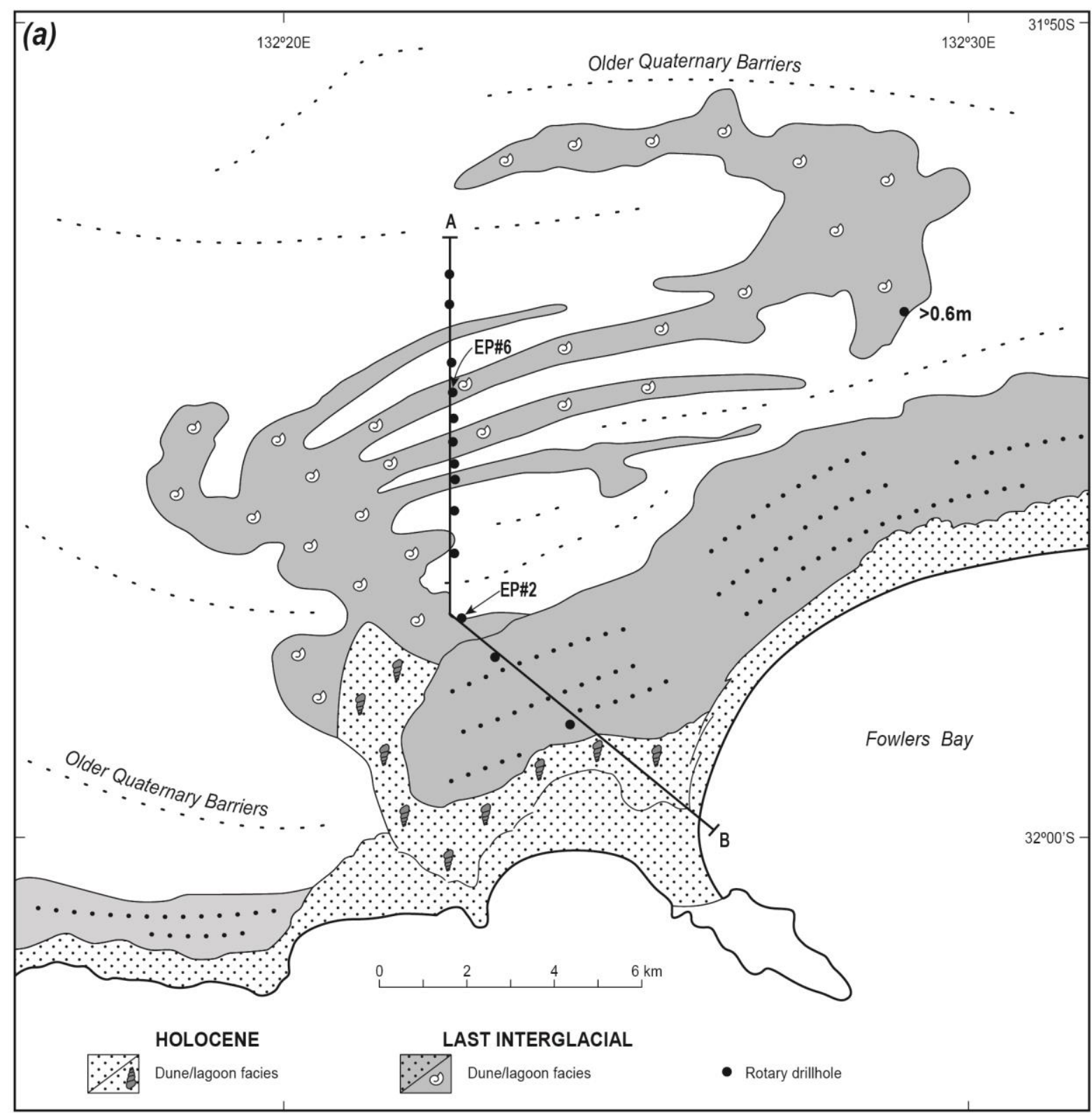

(b)

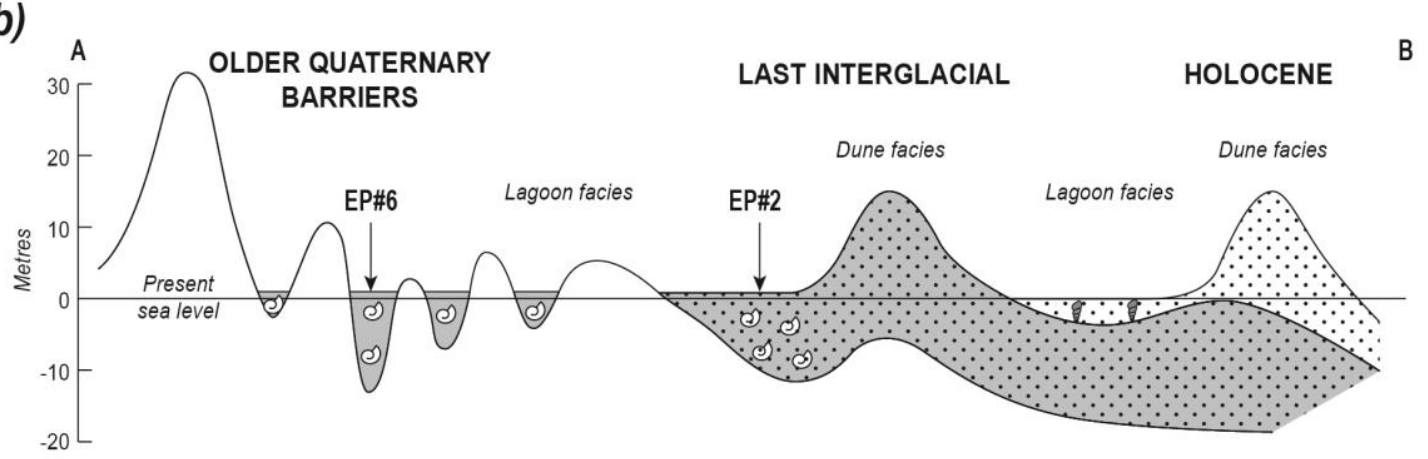


Figure 3

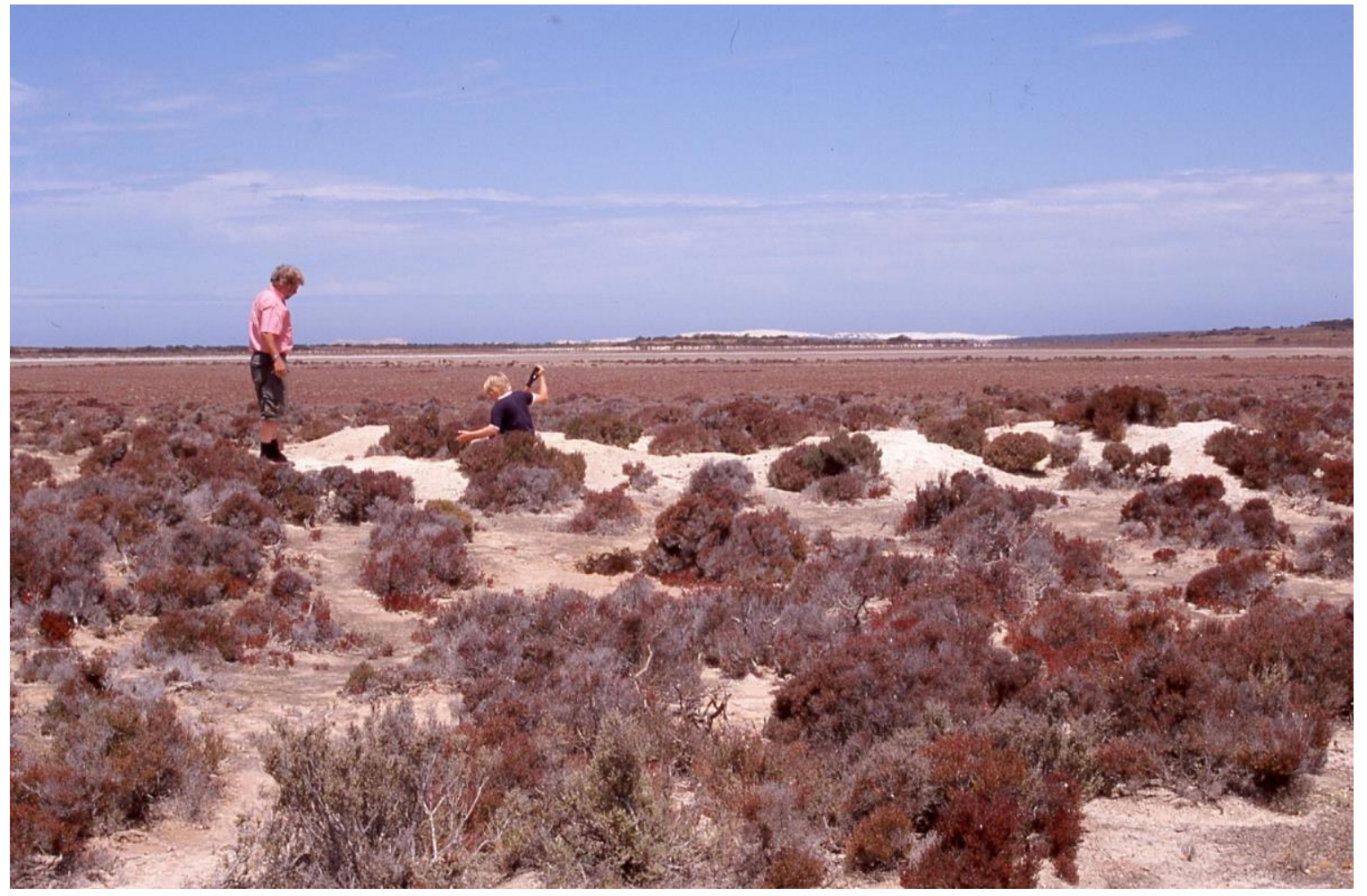

Figure 4

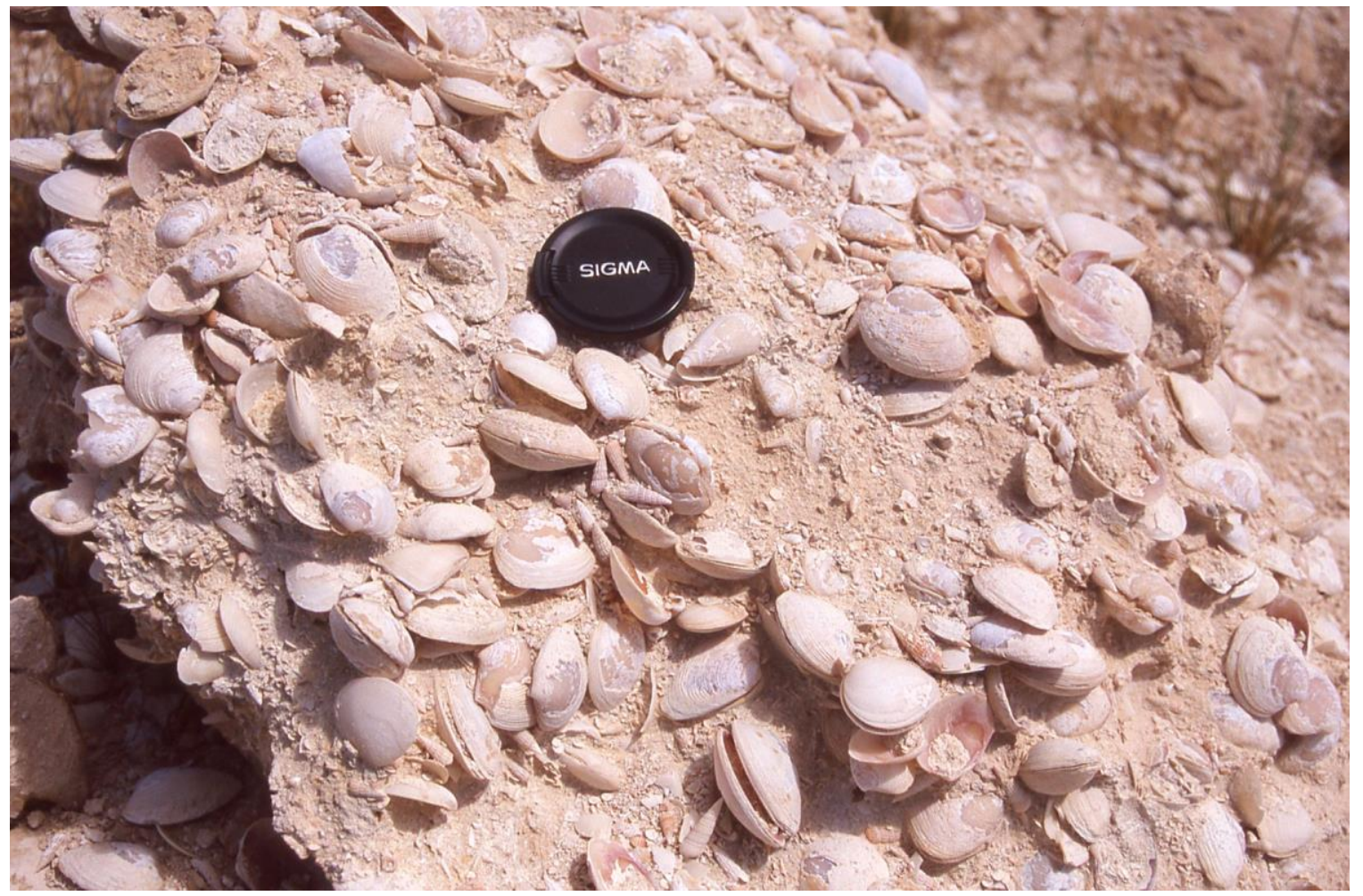


Figure 5

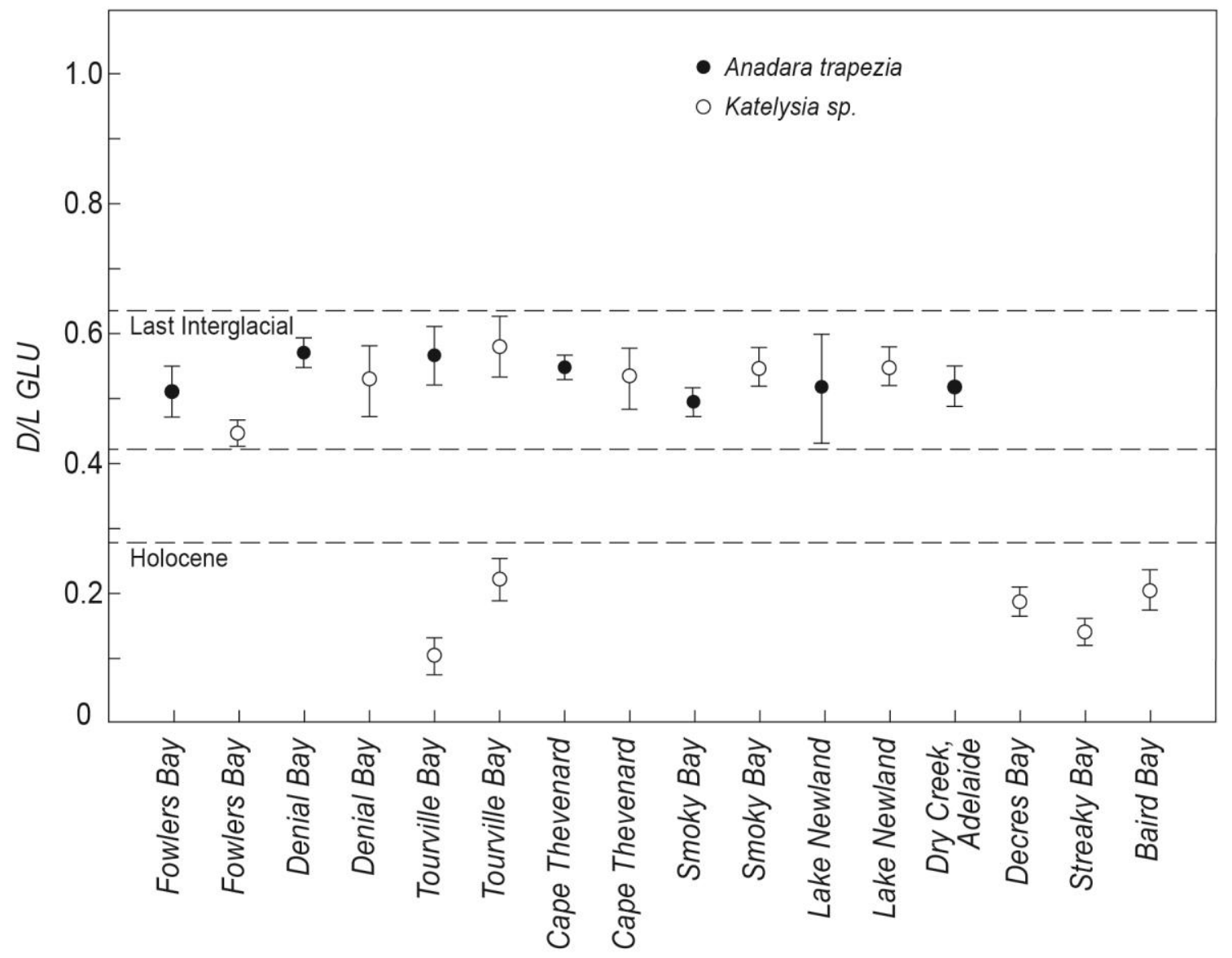


Figure 6

(a)

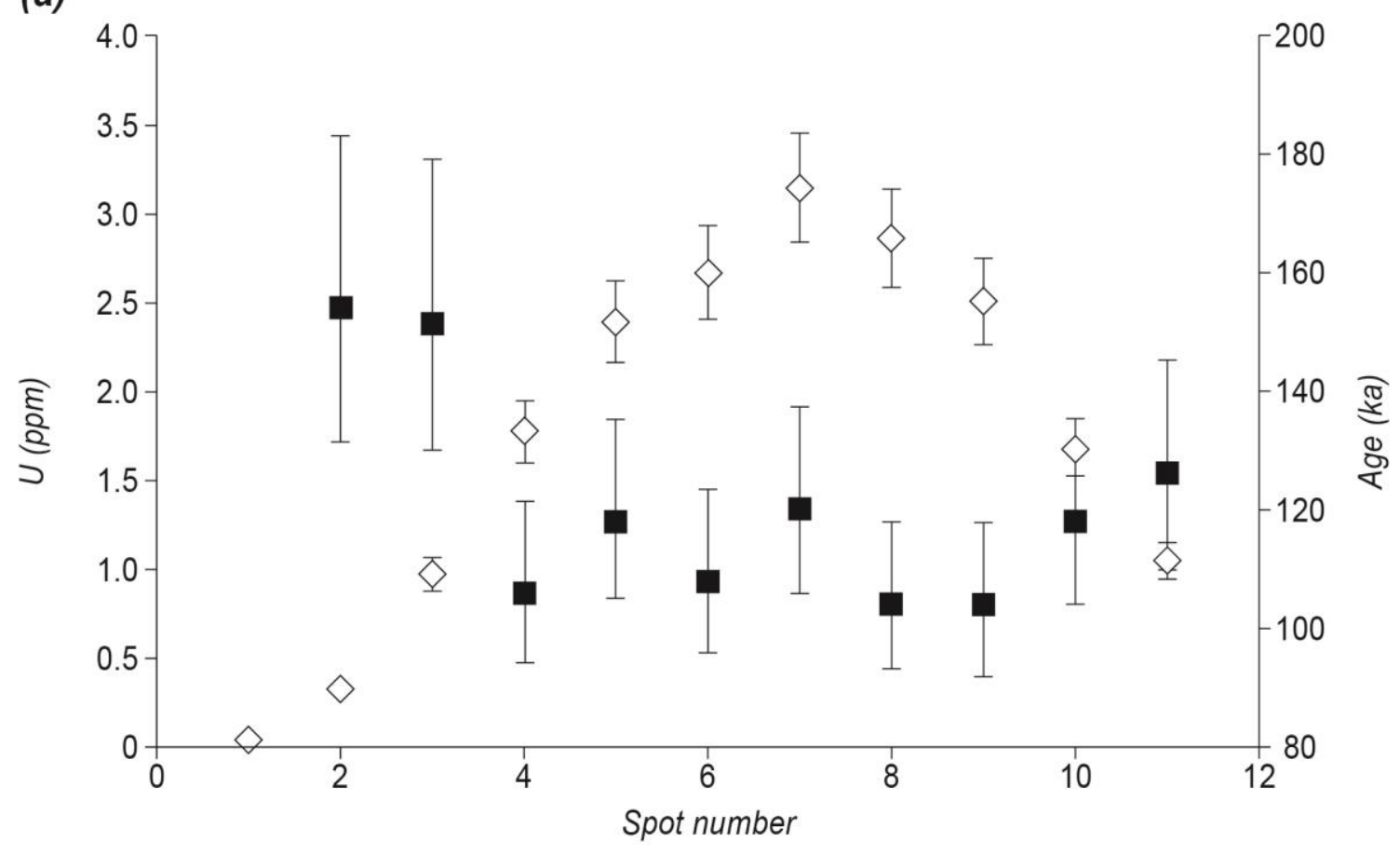

(b)

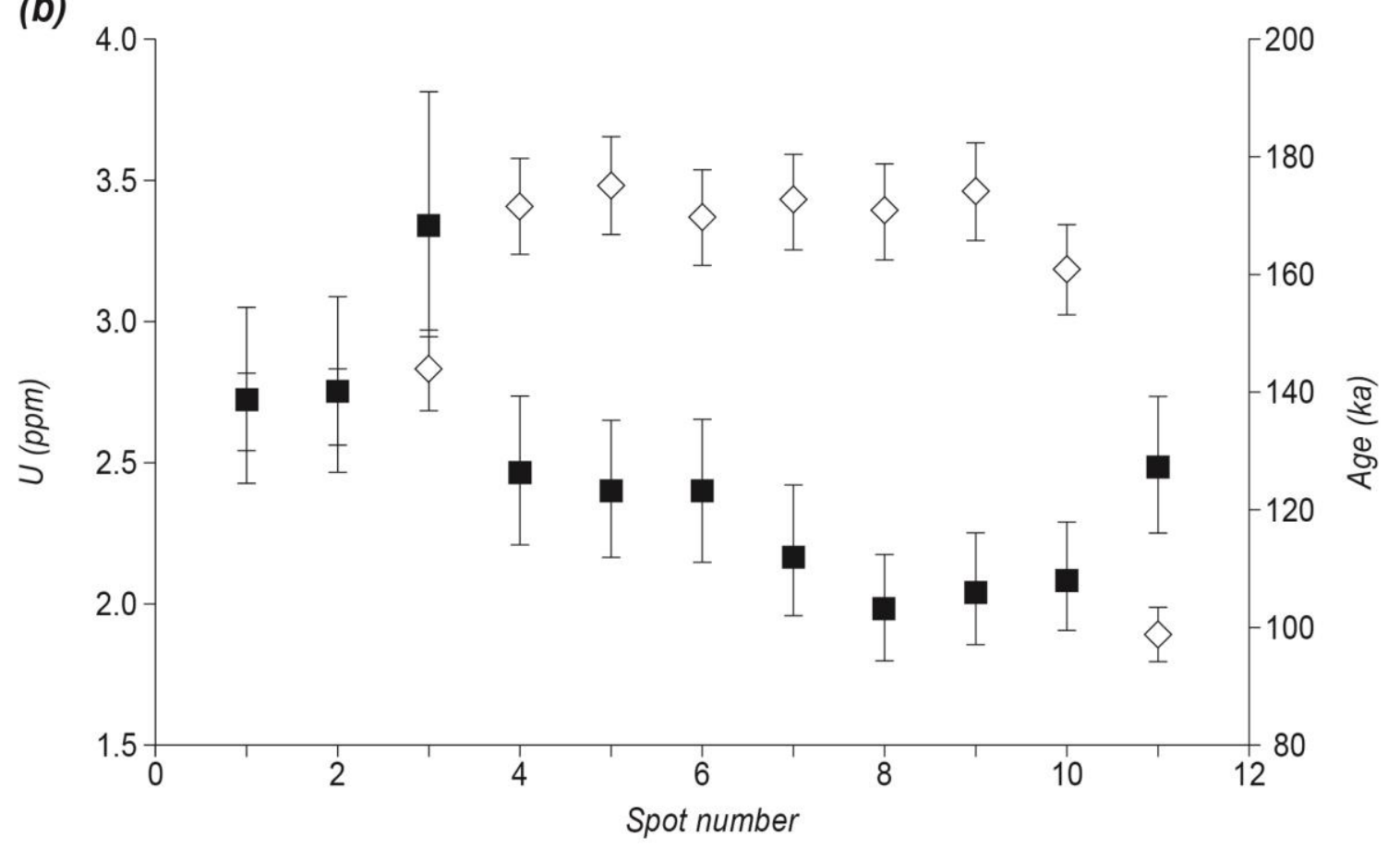


Table 1 Fossil mollusc species and palaeoenvironments of the late Pleistocene Glanville Formation, Eyre Peninsula, South Australia.

\begin{tabular}{|c|c|c|}
\hline Mollusc species & Habitat & References \\
\hline \multicolumn{3}{|l|}{ Bivalves } \\
\hline Anadara trapezia & $\begin{array}{l}\text { Common on intertidal mudflats within } \\
\text { estuaries, shallow burrowing and semi- } \\
\text { infaunal }\end{array}$ & $\begin{array}{l}\text { Murray-Wallace } \text { et al., } \\
2000 \\
\text { Ludbrook, } 1984\end{array}$ \\
\hline Katelysia rhytiphora & $\begin{array}{l}\text { Common on sandy shores in the lower } \\
\text { intertidal zone, or shallow subtidal waters } \\
\text { immediately below low water limit of } \\
\text { intertidal zone within estuaries }\end{array}$ & $\begin{array}{l}\text { Ludbrook, } 1984 \\
\text { Roberts, } 1984 \\
\text { Nielsen, } 1964\end{array}$ \\
\hline Katelysia scalarina & $\begin{array}{l}\text { Intertidal to shallow subtidal as per } K \text {. } \\
\text { rhytiphora in sandy substrates }\end{array}$ & $\begin{array}{l}\text { Ludbrook, } 1984 \\
\text { Harte, } 1998\end{array}$ \\
\hline Tellina deltoidalis & $\begin{array}{l}\text { Abundant in mud and muddy sand in } \\
\text { middle to lower intertidal zone in } \\
\text { estuaries and sheltered bays }\end{array}$ & Ludbrook, 1984 \\
\hline Mactra australis & $\begin{array}{l}\text { Common in large numbers in sand in the } \\
\text { lower intertidal zone }\end{array}$ & Ludbrook, 1984 \\
\hline Chlamys (Equichlamys) bifrons & $\begin{array}{l}\text { Juveniles attached to firm substrate; } \\
\text { adults mobile on sand and silty } \\
\text { substrates in water } 2-30 \mathrm{~m}\end{array}$ & $\begin{array}{l}\text { Ludbrook, } 1984 \\
\text { Macpherson \& Gabriel, } 1962\end{array}$ \\
\hline $\begin{array}{l}\text { Brachidontes (Austromytilus) } \\
\text { rostratus }\end{array}$ & $\begin{array}{l}\text { Attached to rocks in the upper to mid } \\
\text { intertidal zone (barnacle-mussel zone) } \\
\text { on rock platforms on open ocean coasts }\end{array}$ & $\begin{array}{l}\text { Ludbrook, } 1984 \\
\text { Macpherson \& Gabriel, } 1962\end{array}$ \\
\hline Spisula (Notospisula) trigonella & $\begin{array}{l}\text { Lives in mud or sandy mud within } \\
\text { estuaries and particularly near river } \\
\text { mouths }\end{array}$ & Ludbrook, 1984 \\
\hline Pinna bicolor & $\begin{array}{l}\text { Subtidal environments partially covered } \\
\text { in sediment apex-down in low to } \\
\text { moderate wave energy }\end{array}$ & Ludbrook, 1984 \\
\hline Cardita sp. & $\begin{array}{l}\text { Lives under rocks in a range of water } \\
\text { depths }(1-20 \mathrm{~m}) \text { with medium to high } \\
\text { energy currents }\end{array}$ & Ludbrook, 1984 \\
\hline \multicolumn{3}{|l|}{ Gastropods } \\
\hline $\begin{array}{l}\text { Batillaria (Zeacumantus) } \\
\text { diemenensis }\end{array}$ & $\begin{array}{l}\text { Intertidal sand or mud flats and feed by } \\
\text { crawling just below the sediment - } \\
\text { water interface creating well-defined } \\
\text { feeding traces }\end{array}$ & $\begin{array}{l}\text { Ludbrook, } 1984 \\
\text { Macpherson \& Gabriel, } 1962\end{array}$ \\
\hline Bulla botanica & $\begin{array}{l}\text { Lives in sandy muds and within weed on } \\
\text { tidal flats in estuaries }\end{array}$ & Ludbrook, 1984 \\
\hline Conus anemone & $\begin{array}{l}\text { Common on rock in the infralittoral } \\
\text { fringe, particularly within rock pools }\end{array}$ & $\begin{array}{l}\text { Ludbrook, } 1984 \\
\text { Macpherson \& Gabriel, } 1962\end{array}$ \\
\hline Fusinus australis & $\begin{array}{l}\text { In sand and silt or near seagrass in } \\
\text { shallow subtidal zone }\end{array}$ & Ludbrook, 1984 \\
\hline Penion mandarinus & $\begin{array}{l}\text { In sand near rocky shorelines in lower } \\
\text { intertidal to shallow subtidal zones }\end{array}$ & Ludbrook, 1984 \\
\hline Nerita atramentosa & $\begin{array}{l}\text { Common in supratidal to intertidal } \\
\text { zones, feeding on algae coating rocks }\end{array}$ & Ludbrook, 1984 \\
\hline
\end{tabular}


Table 2: Extent of amino acid racemization (total hydrolysable amino acids THAA) in fossil marine molluscs, from the late Pleistocene Glanville Formation, western Eyre Peninsula, South Australia.

\begin{tabular}{|c|c|c|c|c|c|c|}
\hline \multirow{2}{*}{$\begin{array}{l}\text { Location \& } \\
\text { Field sample code }\end{array}$} & \multirow{2}{*}{ Lab. Code } & \multirow{2}{*}{ species } & \multirow[b]{2}{*}{ ASP } & \multicolumn{2}{|c|}{ Amino acid D/L value $\dagger$} & \multirow[b]{2}{*}{ PHE } \\
\hline & & & & GLU & VAL & \\
\hline $\begin{array}{l}\text { Dry Creek, Adelaide Plains, } \\
\text { Glanville Formation } \\
\text { Reference section }\end{array}$ & UWGA-5532A-F & Anadara trapezia & $0.674 \pm 0.063$ & $0.523 \pm 0.025$ & $0.516 \pm 0.068$ & $0.671 \pm 0.037$ \\
\hline Fowlers Bay (EP\#2) & UWGA-6100A-C & Katelysia rhytiphora & $0.660 \pm 0.047$ & $0.445 \pm 0.010$ & $0.355 \pm 0.034$ & $0.561 \pm 0.069$ \\
\hline $\mathrm{S} 31^{\circ} 57^{\prime} 06.9^{\prime \prime} ; \mathrm{E} 132^{\circ} 22^{\prime} 43.1^{\prime \prime}$ & UWGA-6103A-C & Anadara trapezia & $0.710 \pm 0.006$ & $0.502 \pm 0.024$ & $0.471 \pm 0.021$ & $0.673 \pm 0.052$ \\
\hline Fowlers Bay (EP\#6) & UWGA-6119A-B & Anadara trapezia & $0.719 \pm 0.019$ & $0.491 \pm 0.018$ & $0.448 \pm 0.030$ & $0.747 \pm 0.025$ \\
\hline 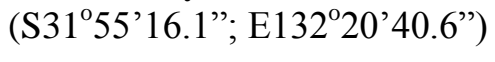 & UWGA-6121A-B & Anadara trapezia & $0.709 \pm 0.077$ & $0.543 \pm 0.078$ & $0.473 \pm 0.064$ & $0.772 \pm 0.048$ \\
\hline Tourville Bay (EP\#8) & UWGA-6007A-D & Chlamys sp. & $0.569 \pm 0.018$ & $0.402 \pm 0.013$ & $0.485 \pm 0.009$ & $0.777 \pm 0.017$ \\
\hline \multirow[t]{8}{*}{$\mathrm{S} 32^{\circ} 08^{\prime} 14.5^{\prime \prime} ; \mathrm{E} 133^{\circ} 23^{\prime} 52.0^{\prime \prime}$} & UWGA-6009A-E & Katelysia rhytiphora & $0.707 \pm 0.003$ & $0.590 \pm 0.028$ & $0.482 \pm 0.022$ & $0.760 \pm 0.031$ \\
\hline & UWGA-6010A-C & Brachidontes rostratus & $0.720 \pm 0.015$ & $0.634 \pm 0.011$ & $0.441 \pm 0.025$ & $0.814 \pm 0.033$ \\
\hline & UWGA-6011A-D & Katelysia rhytiphora & $0.710 \pm 0.016$ & $0.571 \pm 0.022$ & $0.482 \pm 0.008$ & $0.735 \pm 0.027$ \\
\hline & UWGA-6012A-F & Katelysia sp. & $0.740 \pm 0.030$ & $0.609 \pm 0.055$ & $0.494 \pm 0.048$ & $0.763 \pm 0.087$ \\
\hline & UWGA-6013A-F & Katelysia sp. & $0.721 \pm 0.039$ & $0.630 \pm 0.050$ & $0.518 \pm 0.043$ & $0.833 \pm 0.063$ \\
\hline & UWGA-6014A-E & Katelysia rhytiphora & $0.609 \pm 0.027$ & $0.511 \pm 0.030$ & $0.390 \pm 0.038$ & $0.585 \pm 0.079$ \\
\hline & UWGA-6015A-C & Anadara trapezia & $0.654 \pm 0.043$ & $0.541 \pm 0.040$ & $0.425 \pm 0.027$ & $0.671 \pm 0.031$ \\
\hline & UWGA-6016A-E & Anadara trapezia & $0.700 \pm 0.027$ & $0.592 \pm 0.033$ & $0.482 \pm 0.040$ & $0.726 \pm 0.030$ \\
\hline Denial Bay (EP\#1) & UWGA-6002A-C & Katelysia sp. & $0.668 \pm 0.063$ & $0.536 \pm 0.055$ & $0.457 \pm 0.041$ & $0.638 \pm 0.098$ \\
\hline \multirow[t]{3}{*}{ S32 06’01.3"; E133³4'46.3" } & UWGA-6003A-E & Katelysia rhytiphora & $0.698 \pm 0.019$ & $0.537 \pm 0.052$ & $0.480 \pm 0.075$ & $0.670 \pm 0.061$ \\
\hline & UWGA-6005A-B & Tellina deltoidalis & $0.680 \pm 0.001$ & $0.592 \pm 0.017$ & $0.545 \pm 0.008$ & $0.708 \pm 0.026$ \\
\hline & UWGA-6006A-E & Anadara trapezia & $0.738 \pm 0.056$ & $0.572 \pm 0.022$ & $0.506 \pm 0.053$ & $0.683 \pm 0.031$ \\
\hline
\end{tabular}


Cape Thevenard, Ceduna (EP\#11)UWGA-6023A-E

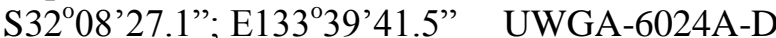
UWGA-6025A-D

Cape Thevenard, Ceduna (EP\#12)UWGA-6029A-B S32 08'26.3"; E13339'39.8" UWGA-6030A-F UWGA-6031A-E UWGA-6032A-B

Smoky Bay (EP\#14-1)

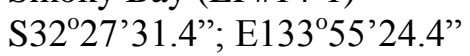

UWGA-6042A-D UWGA-6043A-D UWGA-6044A-C UWGA-6045A-C UWGA-6046A-B UWGA-6047A-E UWGA-6048A-D UWGA-6049A-D UWGA-6050A-B UWGA-6051A-C UWGA-6052A-C

Lake Newland (EP\#19-2)

UWGA-6075A-C S33 25'10.2”; E134'52'55.3”; beneath calcrete)

UWGA-6078A-D UWGA-6079A-G UWGA-6086A-E UWGA-6087A-C UWGA-6088A-C
Anadara sp.

Conus anemone

Katelysia sp.

Katelysia sp.

Anadara trapezia

Katelysia sp.

Katelysia sp.

Katelysia sp.

Katelysia sp.

Batillaria sp.

Batillaria sp.

Batillaria sp.

Bulla botanica

Anadara trapezia

Anadara trapezia

Katelysia sp.

Katelysia rhytiphora

Katelysia rhytiphora

Anadara trapezia

Penion mandarinus

Fusinus australis

Anadara trapezia

Anadara trapezia

Katelysia sp.

\begin{tabular}{|c|c|c|c|}
\hline $0.642 \pm 0.052$ & $0.547 \pm 0.014$ & $0.493 \pm 0.016$ & $0.602 \pm 0.033$ \\
\hline $0.578 \pm 0.044$ & $0.405 \pm 0.056$ & $0.399 \pm 0.056$ & $0.333 \pm 0.017$ \\
\hline $0.690 \pm 0.008$ & $0.539 \pm 0.041$ & $0.500 \pm 0.058$ & $0.634 \pm 0.035$ \\
\hline $0.669 \pm 0.008$ & $0.541 \pm 0.025$ & $0.589 \pm 0.045$ & \\
\hline $0.660 \pm 0.013$ & $0.571 \pm 0.016$ & $0.580 \pm 0.045$ & $0.716 \pm 0.02$ \\
\hline $0.686 \pm 0.029$ & $0.573 \pm 0.058$ & $0.468 \pm 0.024$ & $0.718 \pm 0.02$ \\
\hline $0.683 \pm 0.012$ & $0.569 \pm 0.044$ & $0.612 \pm 0.058$ & 0.766 \\
\hline $0.682 \pm 0.016$ & $0.538 \pm 0.026$ & $0.471 \pm 0.037$ & $0.708 \pm 0.036$ \\
\hline $0.683 \pm 0.002$ & $0.583 \pm 0.025$ & $0.551 \pm 0.030$ & $0.794 \pm 0.03$ \\
\hline $0.598 \pm 0.046$ & $0.431 \pm 0.051$ & $0.404 \pm 0.029$ & $0.506 \pm 0.042$ \\
\hline $0.634 \pm 0.026$ & $0.437 \pm 0.025$ & $0.479 \pm 0.079$ & $0.549 \pm 0.03$ \\
\hline $0.722 \pm 0.018$ & $0.557 \pm 0.018$ & $0.459 \pm 0.030$ & $0.681 \pm 0.00$ \\
\hline $0.677 \pm 0.039$ & $0.532 \pm 0.038$ & $0.634 \pm 0.097$ & $0.640 \pm 0.11$ \\
\hline $0.711 \pm 0.070$ & $0.502 \pm 0.030$ & $0.435 \pm 0.042$ & $0.642 \pm 0.03$ \\
\hline $0.677 \pm 0.009$ & $0.493 \pm 0.010$ & $0.402 \pm 0.009$ & $0.551 \pm 0.02$ \\
\hline $0.679 \pm 0.010$ & $0.545 \pm 0.035$ & $0.494 \pm 0.028$ & $0.711 \pm 0.019$ \\
\hline $0.687 \pm 0.008$ & $0.557 \pm 0.016$ & $0.468 \pm 0.012$ & $0.705 \pm 0.00$ \\
\hline $0.681 \pm 0.020$ & $0.535 \pm 0.037$ & $0.511 \pm 0.010$ & $0.648 \pm 0.06$ \\
\hline $0.615 \pm 0.035$ & $0.423 \pm 0.091$ & $0.439 \pm 0.092$ & $0.326 \pm 0.004$ \\
\hline $0.673 \pm 0.017$ & $0.568 \pm 0.031$ & $0.471 \pm 0.012$ & $0.595 \pm 0.042$ \\
\hline $0.734 \pm 0.026$ & $0.563 \pm 0.036$ & $0.527 \pm 0.023$ & $0.452 \pm 0.032$ \\
\hline $0.839 \pm 0.005$ & $0.599 \pm 0.037$ & $0.543 \pm 0.023$ & $0.758 \pm 0.101$ \\
\hline $0.806 \pm 0.033$ & $0.563 \pm 0.077$ & $0.505 \pm 0.117$ & 0.649 \\
\hline $0.758 \pm 0.006$ & $0.557 \pm 0.018$ & $0.451 \pm 0.033$ & $0.608 \pm 0.02$ \\
\hline
\end{tabular}

$\uparrow$ Amino acids: ASP - aspartic acid; GLU - glutamic acid; VAL - valine; PHE - phenylalanine. 
Table 3 Extent of amino acid racemization (total hydrolysable amino acids, THAA) in fossil molluscs from the Holocene St Kilda Formation, western Eyre Peninsula, South Australia.

\begin{tabular}{|c|c|c|c|c|c|c|}
\hline \multirow{2}{*}{$\begin{array}{l}\text { Location \& } \\
\text { Field sample code }\end{array}$} & \multirow[t]{2}{*}{ Lab. Code } & \multirow[t]{2}{*}{ species } & \multicolumn{4}{|c|}{ Amino acid D/L value $\dagger$} \\
\hline & & & ASP & GLU & VAL & PHE \\
\hline Tourville Bay (EP\#9) & UWGA-6017A-C & Katelysia sp. & $0.387 \pm 0.016$ & $0.226 \pm 0.023$ & $0.177 \pm 0.034$ & $0.258 \pm 0.035$ \\
\hline \multirow[t]{2}{*}{ S32 $08^{\circ} 17.0^{\prime \prime} ;$ E133'ㄱ'48.4" } & UWGA-6018A-D & Cardita sp. & $0.435 \pm 0.035$ & $0.201 \pm 0.007$ & $0.132 \pm 0.005$ & $0.207 \pm 0.010$ \\
\hline & UWGA-6019A-B & Katelysia sp. & $0.363 \pm 0.004$ & $0.157 \pm 0.017$ & $0.113 \pm 0.023$ & $0.181 \pm 0.008$ \\
\hline Decres Bay, Ceduna (EP\#13) & UWGA-6033A-C & Katelysia sp. & $0.349 \pm 0.005$ & $0.195 \pm 0.004$ & $0.149 \pm 0.005$ & $0.223 \pm 0.006$ \\
\hline \multirow[t]{6}{*}{$\mathrm{S} 32^{\circ} 13^{\prime} 28.1^{\prime \prime} ; \mathrm{E} 133^{\circ} 48^{\prime} 45.4^{\prime \prime}$} & UWGA-6034A-C & Katelysia sp. & $0.359 \pm 0.005$ & $0.188 \pm 0.006$ & $0.142 \pm 0.013$ & $0.201 \pm 0.008$ \\
\hline & UWGA-6035A-B & Katelysia sp. & $0.475 \pm 0.034$ & $0.208 \pm 0.006$ & $0.183 \pm 0.018$ & $0.262 \pm 0.004$ \\
\hline & UWGA-6036A-B & Katelysia sp. & $0.386 \pm 0.034$ & $0.210 \pm 0.028$ & $0.152 \pm 0.034$ & $0.266 \pm 0.052$ \\
\hline & UWGA-6037A-B & Katelysia sp. & $0.346 \pm 0.008$ & $0.160 \pm 0.006$ & $0.100 \pm 0.005$ & $0.187 \pm 0.007$ \\
\hline & UWGA-6038A-B & Katelysia sp. & $0.382 \pm 0.010$ & $0.162 \pm 0.010$ & $0.111 \pm 0.006$ & $0.253 \pm 0.035$ \\
\hline & UWGA-6039A-C & Katelysia sp. & $0.456 \pm 0.011$ & $0.215 \pm 0.006$ & $0.154 \pm 0.004$ & $0.347 \pm 0.007$ \\
\hline Streaky Bay (EP\#15-1) & UWGA-6053A-D & Katelysia sp. & $0.344 \pm 0.011$ & $0.145 \pm 0.006$ & $0.095 \pm 0.003$ & $0.160 \pm 0.005$ \\
\hline \multirow[t]{6}{*}{$\mathrm{S} 32^{\circ} 41^{\prime} 40.2^{\prime \prime} ; \mathrm{E} 134^{\circ} 17^{\prime} 55.0^{\prime \prime}$} & UWGA-6054A-D & Katelysia sp. & $0.412 \pm 0.019$ & $0.139 \pm 0.003$ & $0.085 \pm 0.004$ & $0.183 \pm 0.007$ \\
\hline & UWGA-6055A-E & Katelysia sp. & $0.381 \pm 0.011$ & $0.146 \pm 0.008$ & $0.084 \pm 0.010$ & $0.168 \pm 0.009$ \\
\hline & UWGA-6056A-D & Katelysia sp. & $0.333 \pm 0.016$ & $0.135 \pm 0.003$ & $0.074 \pm 0.003$ & $0.147 \pm 0.009$ \\
\hline & UWGA-6057A-E & Nerita atramentosa & $0.525 \pm 0.057$ & $0.160 \pm 0.018$ & $0.144 \pm 0.034$ & $0.239 \pm 0.009$ \\
\hline & UWGA-6058A-C & Penion mandarinus & $0.654 \pm 0.011$ & $0.325 \pm 0.012$ & $0.227 \pm 0.020$ & $0.495 \pm 0.020$ \\
\hline & UWGA-6059A-D & Conus sp. & $0.465 \pm 0.035$ & $0.183 \pm 0.015$ & $0.153 \pm 0.019$ & $0.229 \pm 0.027$ \\
\hline \multirow{4}{*}{$\begin{array}{l}\text { Baird Bay (EP\#16-1) } \\
\text { S33 }^{\circ} 05^{\prime} 18.8^{\prime \prime} ; \text { E134 } 19{ }^{\prime} 53.4^{\prime \prime}\end{array}$} & UWGA-6060A-D & Katelysia sp. & $0.374 \pm 0.013$ & $0.172 \pm 0.006$ & $0.121 \pm 0.007$ & $0.193 \pm 0.021$ \\
\hline & UWGA-6061A-E & Katelysia sp. & $0.389 \pm 0.012$ & $0.188 \pm 0.009$ & $0.127 \pm 0.014$ & $0.215 \pm 0.017$ \\
\hline & UWGA-6062A-D & Katelysia sp. & $0.434 \pm 0.014$ & $0.237 \pm 0.008$ & $0.223 \pm 0.024$ & $0.277 \pm 0.028$ \\
\hline & UWGA-6063A-D & Katelysia sp. & $0.373 \pm 0.015$ & $0.168 \pm 0.021$ & $0.099 \pm 0.023$ & $0.197 \pm 0.034$ \\
\hline \multicolumn{7}{|l|}{ Modern molluscs } \\
\hline & UWGA-6097A-C & Katelysia rhytiphora & $0.085 \pm 0.008$ & $0.038 \pm 0.002$ & $0.014 \pm 0.001$ & $0.037 \pm 0.007$ \\
\hline \multirow[t]{2}{*}{$\mathrm{S} 34^{\circ} 36^{\prime} 56.6^{\prime \prime} ; \mathrm{E} 134^{\circ} 27^{\prime} 47.0^{\prime \prime}$} & UWGA-6098A-C & Katelysia rhytiphora & $0.096 \pm 0.008$ & $0.042 \pm 0.001$ & $0.014 \pm 0.000$ & $0.036 \pm 0.002$ \\
\hline & UWGA-6099A-B & Spisula trigonella & $0.068 \pm 0.008$ & 0.033 & $0.013 \pm 0.000$ & $0.029 \pm 0.001$ \\
\hline
\end{tabular}

$\dagger$ Amino acids: ASP - aspartic acid; GLU - glutamic acid; VAL - valine; PHE - phenylalanine. 
Table 4 Aminostratigraphical correlation of the last interglacial Glanville Formation based on the extent of amino acid racemization (total hydroysable amino acids; THAA) in the fossil mollusc Anadara trapezia.

\begin{tabular}{llllll}
\hline Location & $\begin{array}{l}\text { Depth of } \\
\text { burial (m) }\end{array}$ & ASP & GLU & VAL & PHE \\
& & & & \\
& & & & & \\
\hline Glanville Formation & 3 & $0.674 \pm 0.063$ & $0.523 \pm 0.025$ & $0.516 \pm 0.068$ & $0.671 \pm 0.037$ \\
Reference section, & & & & & \\
Dry Creek, Adelaide & 1 & $0.714 \pm 0.007$ & $0.517 \pm 0.037$ & $0.461 \pm 0.017$ & $0.759 \pm 0.018$ \\
Fowlers Bay (EP\#6) & 1 & $0.677 \pm 0.033$ & $0.567 \pm 0.036$ & $0.454 \pm 0.040$ & $0.699 \pm 0.039$ \\
Tourville Bay & 0.5 & $0.738 \pm 0.056$ & $0.572 \pm 0.022$ & $0.506 \pm 0.053$ & $0.683 \pm 0.031$ \\
Denial Bay & 0.3 & $0.651 \pm 0.013$ & $0.559 \pm 0.017$ & $0.537 \pm 0.062$ & $0.602 \pm 0.033$ \\
Thevenard, Ceduna & 1 & $0.694 \pm 0.024$ & $0.498 \pm 0.006$ & $0.419 \pm 0.023$ & $0.597 \pm 0.064$ \\
Smoky Bay & 1 & $0.753 \pm 0.121$ & $0.528 \pm 0.093$ & $0.496 \pm 0.053$ & $0.578 \pm 0.225$ \\
Lake Newland & & & & &
\end{tabular}


Table 5 Results of Uranium-series analyses on the fossil mollusc Anadara trapezia from Fowlers Bay and Lake Newland, western Eyre Peninsula, South Australia.

\begin{tabular}{|c|c|c|c|c|c|c|c|c|c|c|c|c|c|}
\hline E103 & Th (ppb) & U (ppm) & (230Th/232Th) & (230Th/238U) & $2 \sigma$ & (234U/238U) & $2 \sigma$ & Age (ka) & $+2 \sigma$ & $-2 \sigma$ & (234U/238U)init & $+2 \sigma$ & $-2 \sigma$ \\
\hline Spot \#1 & $<$ d.I. & 0.03 & n.d. & 3.047 & 0.129 & 1.49 & 0.08 & n.d. & & & n.d. & & \\
\hline Spot \#2 & $<$ d.I. & 0.32 & n.d. & 0.823 & 0.035 & 1.08 & 0.06 & 154 & 29 & 23 & 1.12 & 0.077 & 0.082 \\
\hline Spot \#3 & $<$ d.I. & 0.97 & n.d. & 0.826 & 0.035 & 1.09 & 0.06 & 151 & 28 & 21 & 1.14 & 0.075 & 0.079 \\
\hline Spot \#4 & 1.14 & 1.77 & n.d. & 0.66 & 0.03 & 1.06 & 0.05 & 106 & 15 & 12 & 1.08 & 0.068 & 0.076 \\
\hline Spot \#5 & $<$ d.I. & 2.38 & n.d. & 0.71 & 0.03 & 1.07 & 0.06 & 118 & 17 & 13 & 1.09 & 0.068 & 0.072 \\
\hline Spot \#6 & $<$ d.I. & 2.66 & 55 & 0.68 & 0.03 & 1.08 & 0.06 & 108 & 15 & 12 & 1.11 & 0.076 & 0.073 \\
\hline Spot \#7 & $<$ d.I. & 3.14 & 91 & 0.72 & 0.03 & 1.07 & 0.06 & 120 & 17 & 14 & 1.1 & 0.071 & 0.074 \\
\hline Spot \#8 & $<$ d.I. & 2.86 & n.d. & 0.66 & 0.03 & 1.07 & 0.06 & 104 & 14 & 11 & 1.09 & 0.069 & 0.07 \\
\hline Spot \#9 & $<$ d.I. & 2.50 & n.d. & 0.64 & 0.03 & 1.04 & 0.05 & 104 & 14 & 12 & 1.06 & 0.068 & 0.072 \\
\hline Spot \#10 & $<$ d.I. & 1.68 & n.d. & 0.71 & 0.03 & 1.06 & 0.05 & 118 & 17 & 14 & 1.08 & 0.073 & 0.075 \\
\hline Spot \#11 & 2.44 & 1.04 & 126 & 0.70 & 0.03 & 1.03 & 0.05 & 126 & 19 & 16 & 1.03 & 0.069 & 0.078 \\
\hline E10 & Th (ppb) & $\mathrm{U}(\mathrm{ppm})$ & (230Th/232Th) & (230Th/238U) & $2 \sigma$ & $(234 \mathrm{U} / 238 \mathrm{U})$ & $2 \sigma$ & Age (ka) & $+2 \sigma$ & $-2 \sigma$ & $(234 U / 238 U)$ init & $+2 \sigma$ & $-2 \sigma$ \\
\hline Spot \#1 & 3.889 & 2.67 & 1934 & 0.78 & 0.03 & 1.07 & 0.03 & 138 & 16 & 14 & 1.104 & 0.043 & 0.043 \\
\hline Spot \#2 & 0.385 & 2.69 & 562 & 0.78 & 0.03 & 1.07 & 0.03 & 140 & 16 & 14 & 1.103 & 0.044 & 0.048 \\
\hline Spot \#3 & $<$ d.I. & 2.82 & n.d. & 0.88 & 0.04 & 1.10 & 0.03 & 168 & 23 & 19 & 1.16 & 0.044 & 0.049 \\
\hline Spot \#4 & $<$ d.I. & 3.41 & 888 & 0.76 & 0.03 & 1.09 & 0.03 & 126 & 13 & 12 & 1.134 & 0.04 & 0.043 \\
\hline Spot \#5 & $<$ d.I. & 3.48 & 1350 & 0.76 & 0.03 & 1.11 & 0.03 & 123 & 12 & 11 & 1.153 & 0.043 & 0.046 \\
\hline Spot \#6 & $<$ d.I. & 3.36 & n.d. & 0.76 & 0.03 & 1.11 & 0.03 & 123 & 12 & 12 & 1.153 & 0.042 & 0.042 \\
\hline Spot \#7 & $<$ d.I. & 3.42 & 287 & 0.73 & 0.03 & 1.12 & 0.03 & 112 & 12 & 10 & 1.168 & 0.042 & 0.044 \\
\hline Spot \#8 & $<$ d.I. & 3.39 & n.d. & 0.70 & 0.03 & 1.13 & 0.03 & 103 & 9.3 & 9.1 & 1.174 & 0.046 & 0.043 \\
\hline Spot \#9 & $<$ d.I. & 3.46 & 2524 & 0.72 & 0.03 & 1.14 & 0.03 & 106 & 9.7 & 9 & 1.193 & 0.04 & 0.042 \\
\hline Spot \#10 & $<$ d.I. & 3.18 & n.d. & 0.72 & 0.03 & 1.13 & 0.03 & 108 & 10 & 8.7 & 1.173 & 0.04 & 0.047 \\
\hline Spot \#11 & 2.278 & 1.89 & 114 & 0.79 & 0.03 & 1.13 & 0.03 & 127 & 12 & 11 & 1.183 & 0.043 & 0.043 \\
\hline
\end{tabular}

